
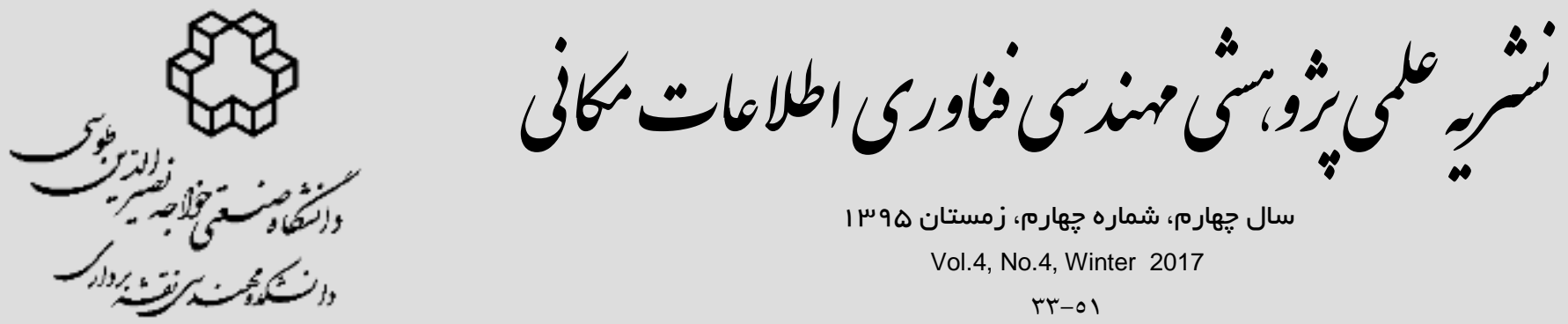

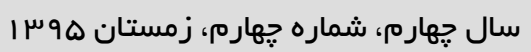

Vol.4, No.4, Winter 2017

rr-01

شناسايى ساختمان در مناطق شهرى با استفاده از تلفيق ويزكىهاى تصاوير نورى و رادارى در شبكه هاى عصبى بـ

مريم تيمورى "، مهدى مختارزاده "، محمدجواد ولدان زوج"

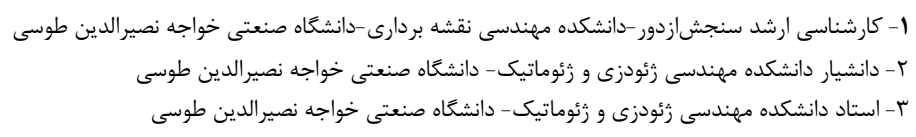

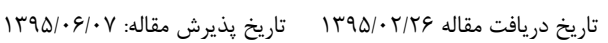

جكيده

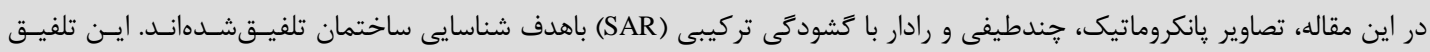

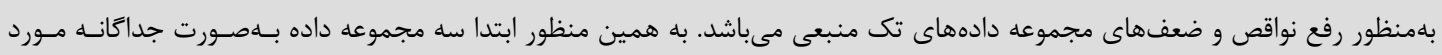

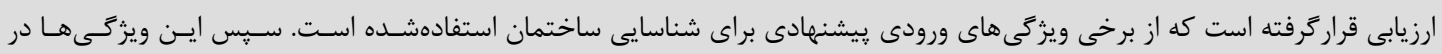

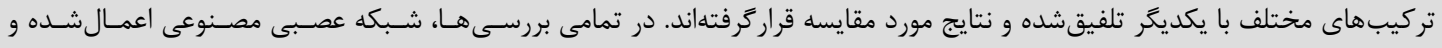

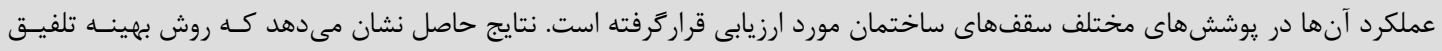

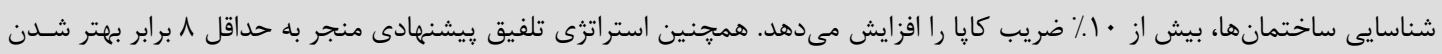

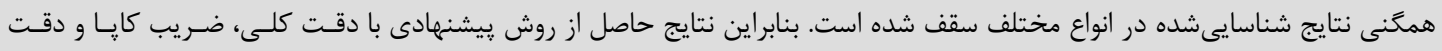

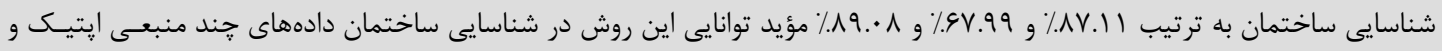
رادار مىباشد.

وازههاى كليدى: شناسايى ساختمان، تلفيق، تصوير رادار، تصوير نورى، شبكهاى عصبى

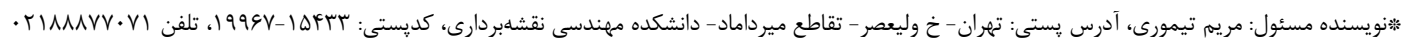
Email:mteimouri@mail.kntu.ac.ir 
استخراج ويزگى و طبقهبندى تصـاوير يانكروماتيـك بـا

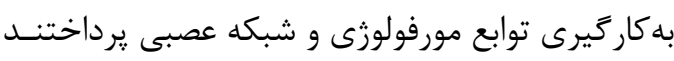

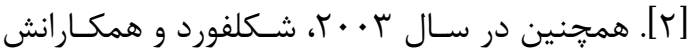
روشى با استفاده از روشهاى لبه مبنا و شىء مبنا براى

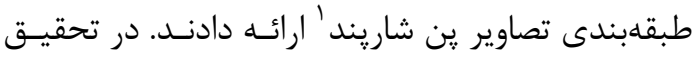
مذكور ابتدا توسط يك طبقهبندى كننده يريكسـل مبنـا

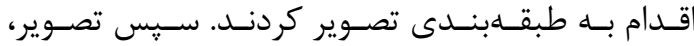

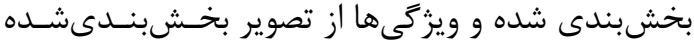

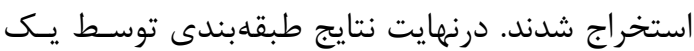
طبقهبندى كننده קٍيكسل مبناى فازى بهببود داده شـــ

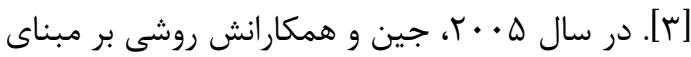

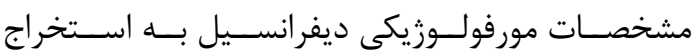
ساختمان از تصاوير يانكروماتيك باقـدرت تفكيـك بـالا

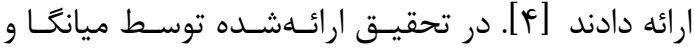

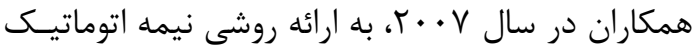

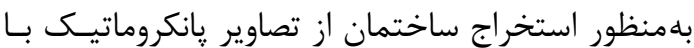
استفاده از الكوريتمهاى منحنى فعال و رديال كاستينگ

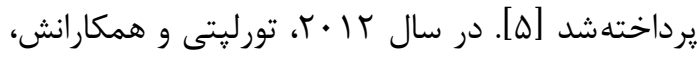
روشـى تركيبـى در اسـتخر اج ســبعـدى ســاختمان

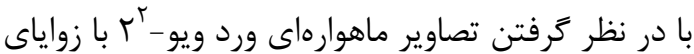

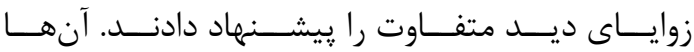

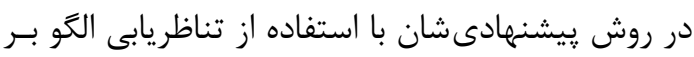
تصوير ين شاريند به استخراج ارتفاع نسبى ساختمانها يرداختند. سيس از طبقهبندى كننــده بـردار رشــيبان

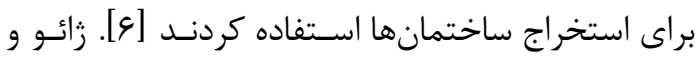

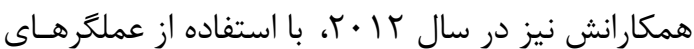

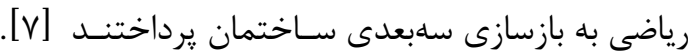

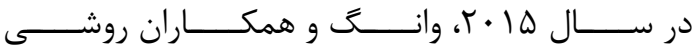
جهت استخراج ساختمان براساس شـكلهـاى هندسى درى اوليه مانند خطوط و خطوط متقاطع ارائه دادنـد. آنهـا

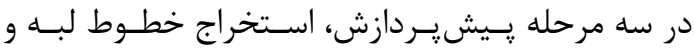
درنهايت با استفاده از يك تراف جستجو ساختمانهاى

\footnotetext{
${ }^{1}$ Pansharpened
}

${ }^{2}$ WorldView-2
| - 1- (- مقدمه

بهمنظور مديريت هرجه بهتر مناطق شهرى و روستايى،

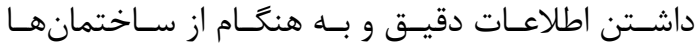

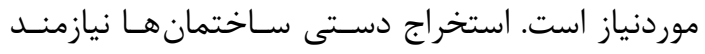
ايراتورهاى ماهر، افزايش زمان و هزينه است. به همـين

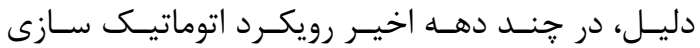

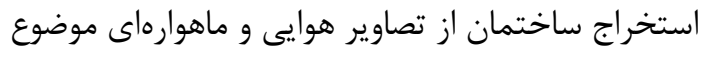

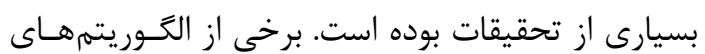

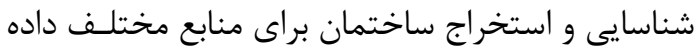

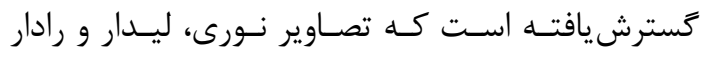

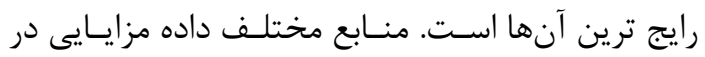
موقعيتهاى مختلف فراهم مى كنند. باينوجـود، آنهـا

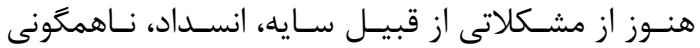

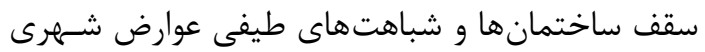

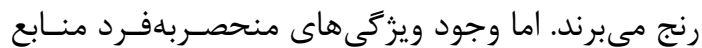
مختلف داده، ايدهاى براى به كار كيرى مزاياى هر منبع و

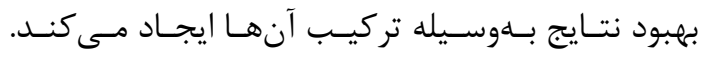

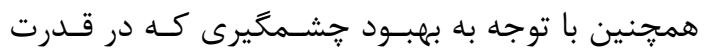
تفكيك مكانى تصاوير نورى و رادارى رخداده است، ايسن

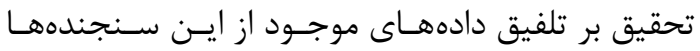
بلمنظور شناسايى عارضه ساختمان متمركزشده است. تصاوير نورى يك منبع غنى از اطلاعات براى شناسـايى

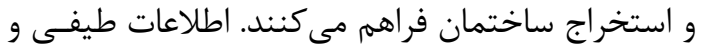

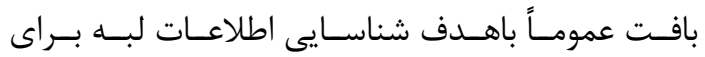

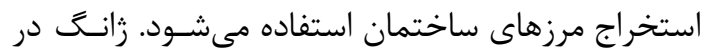
سال 1999 در تحقيقى با استفاده از اطلاعات طيفى و بافت به شناسايى ساختمان يرداخته اسـت. در تحقيـق

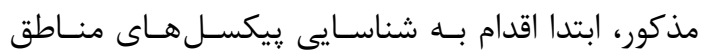

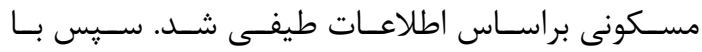

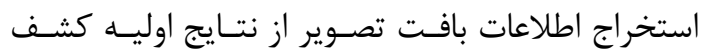
ساختمان، اقدام به ناحيه بندى مجدد، ناحيه اوليه كرد. در ادامه ضمن تلفيق نتيجـه حاصـل از كشـف منــاطق مسكونى، توسط اطلاعات بافت و طيف به بهبـود نتـايج

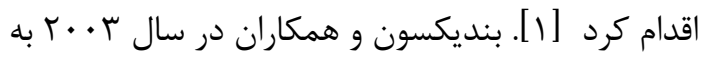


روش هاى مورفولوزيكى به تفكيك مناطق ساختهشده از

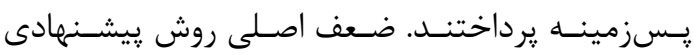
وابستَى الكوريته ارائهشده به انتخاب حد آستانه و نياز

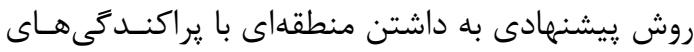

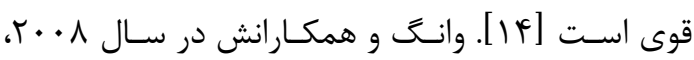

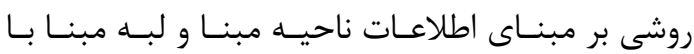
استفاده از داده يلاريمترى با حد تفكيك بالا ارائه دادند

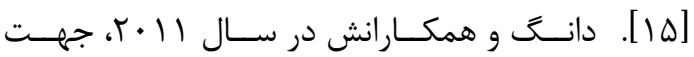

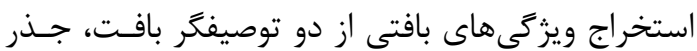

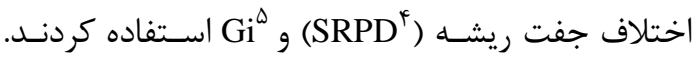

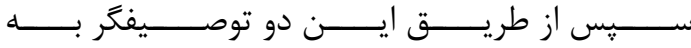
استخراج ساختمانها در مناطق شهرى بـ اسـا اسـتفاده از

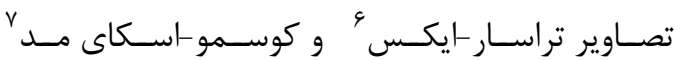
اقدام كردند. در اين روش وجود اغتشــاشهــاى نـويزى

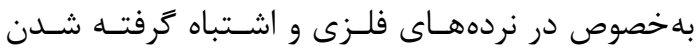
بافت متوسط SRPD و Gi با بافت زبـر منطقـهـ شهرى

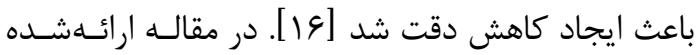

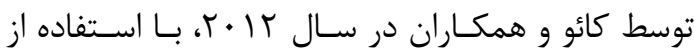

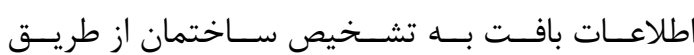

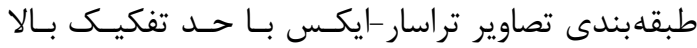

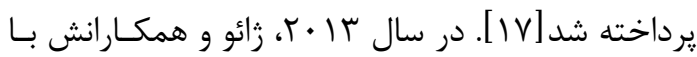

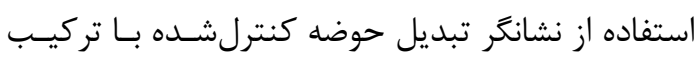

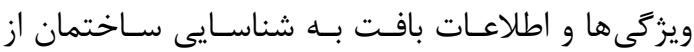
تصوير رادار با گشودگى تركيبى اقدام كردند. ايـن روش

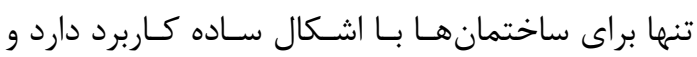

همجنين وابسته به تعيين حد آستانه است [1/1].

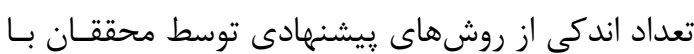

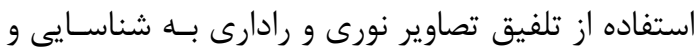

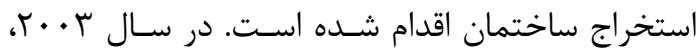

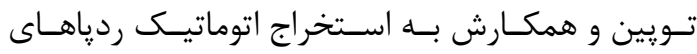

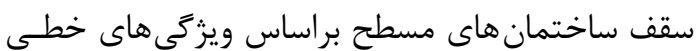

\footnotetext{
${ }^{4}$ Square Root Pair Difference

${ }^{5}$ Getis-Ord

${ }^{6}$ TerraSAR-X

7 COSMO/SkyMed
}

مستطيلى شكل را اسـتخراج كردنــ [N]]. همجنــين در تحقيق صورت كرفته، توسط تركر و كوك سن در سـال ها • r، روشى اتوماتيك جهت استخراج ساختمانهـاى

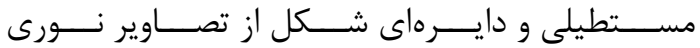

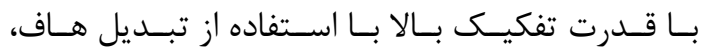

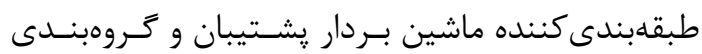

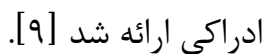
شناسايى ساختمان از تصاوير رادار با گشودگى تركيبسى (SAR') (SAR')

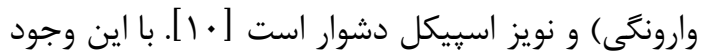

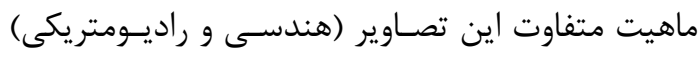

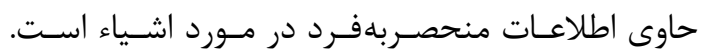

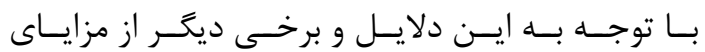

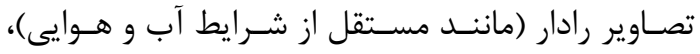
دادههاى مكمل بسيار مناسبى براى شناسايى ساختمان

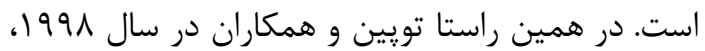

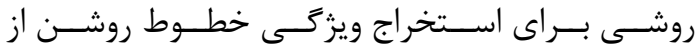

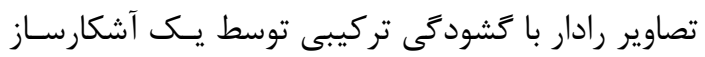

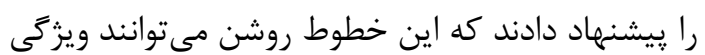

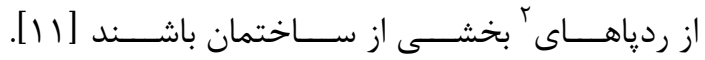

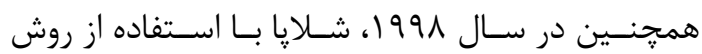

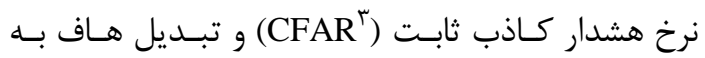

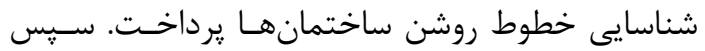
بخشبندى بيشترين احتمال را بـراى شناسـايى سـايه

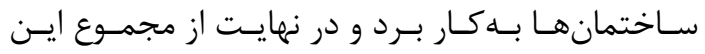

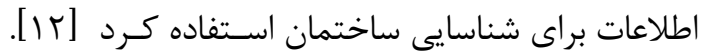

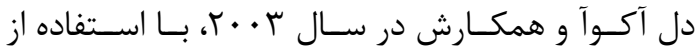

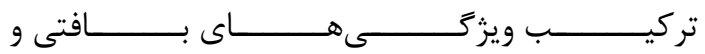
طبقهبندى كننده عصبى_ فازى بـهـ شناسـايى منـاطق

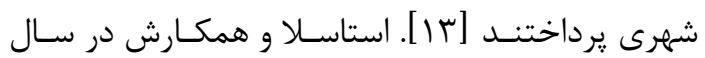

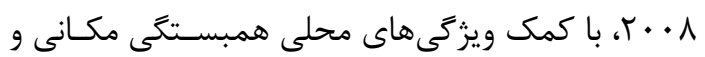

\footnotetext{
${ }^{1}$ Synthetic Aperture Radar

${ }^{2}$ Footprints

${ }^{3}$ Constant False Alarm Rate
} 


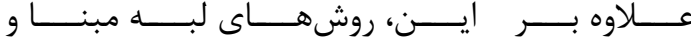

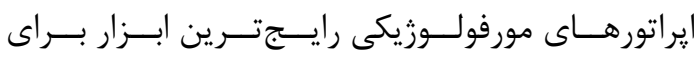

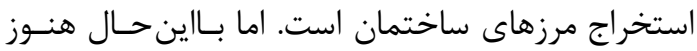

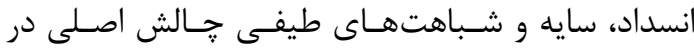
شناسايى ساختمان از تصاوير نورى است.

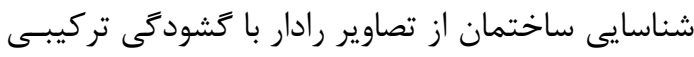
اغلب نيازمند داشتن تصاويرى باقدرت تفكيك يكى متـر

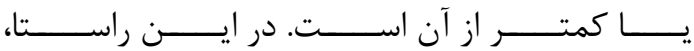

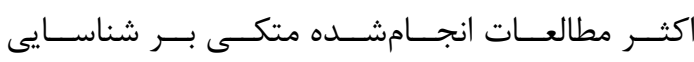

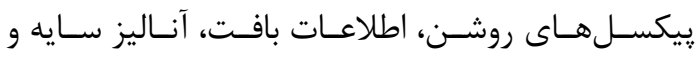

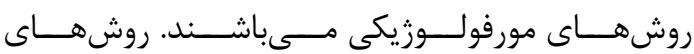

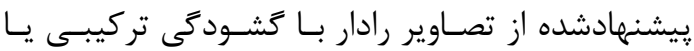
تلفيقى با تصاوير نورى بر ساختمانهاى بـزرك، سـاده، مجزا و بدون پِيجيدگى شهرى تستشده است. در اين تحقيق علاوه بر شناسايى نقاط ضعف هـر منبـع

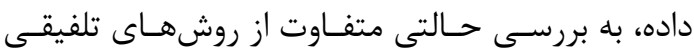
تصاوير نورى و رادارى بيشنهادى توسط محققين تا بـهـ

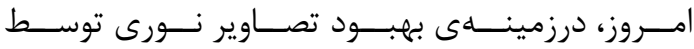

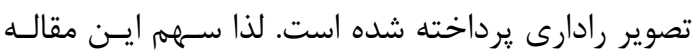

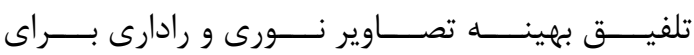

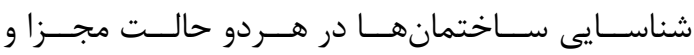
بلوك هاى سـاختمانى از يـك منطقــه يِيجيـده شـهرى

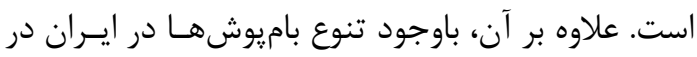

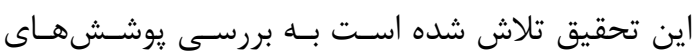

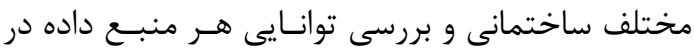
شناسايى آنها يرداخته شود. ادامه سـاختار مقالـه بـه شـرح زيــر اسـت: بخـش دوم،

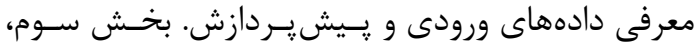

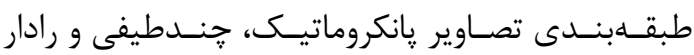

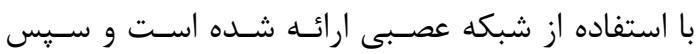
به تلفيق در سطح ويزگى تصاوير يرداختـه شـده اسـت. بخش جهارم خلاصه و نتيجه كيرى بيان شده است.
با استفاده از تصاوير رادار با گششودىى تركيبسى و نـورى

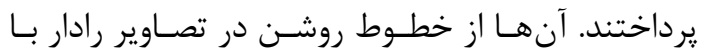

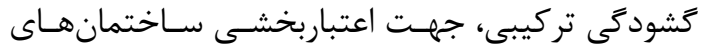
شناسايىشـده توسـط تصـاوير نـورى اسـتفاده كردنـد،

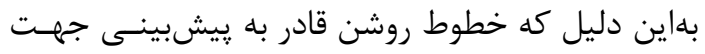
ساختمانها و همجنين بخشى از قسمتهاى ساختمان

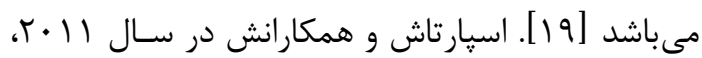

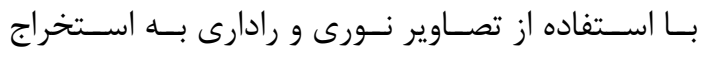

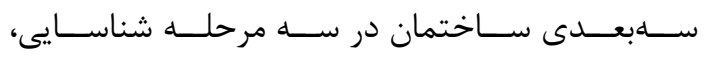

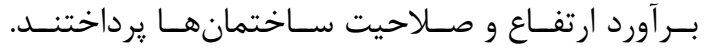

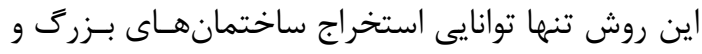

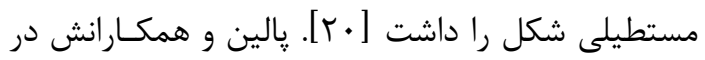

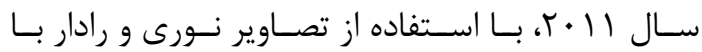
كشودىى تركيبى به توليد و بروز رسانى ساختمانها در

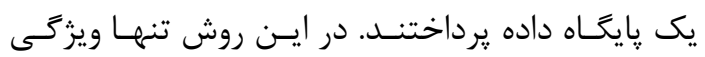

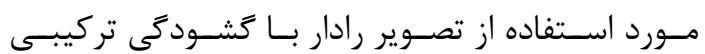
كنتراست مىباشد كه از نسبت ميانكَين وارونكى و سايه تر

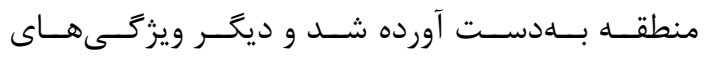

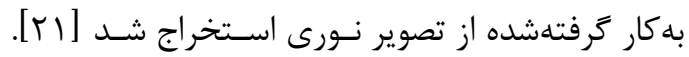

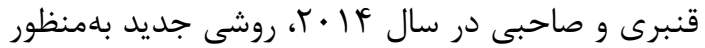

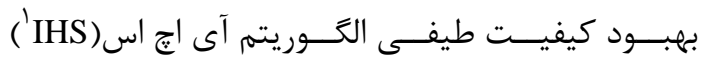

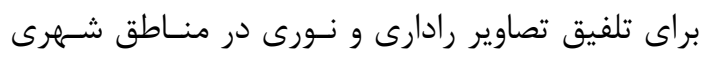

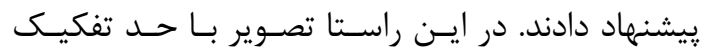

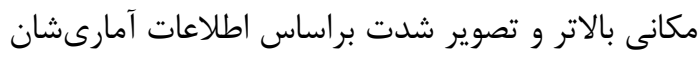
تلفيق شدند. سـيس تصـوير تلفيقى جـايكزئين تصـوير

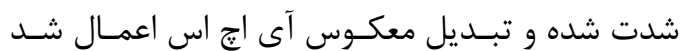

$[$ [rr]

در نكاه كلى بر تحقيقات صورت كرفتـه در شناسـايى و استخراج ساختمان نشان مى دهد كه بيشتر روشها بـر مركر تصاوير نورى توسعه يافته است. در اين موارد شناسـايى

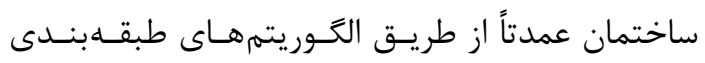

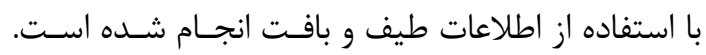

I Intensity-Hue-Saturation 
تـك سـاختمانهـا و بلـوك كهــاى سـاختمانى بــا انـواع

r- مشخصات دادههاى مورداستفاده و

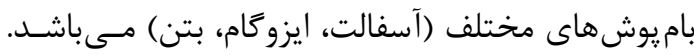
ويشير دازش در ايـن تحقيـق از تصـاوير ســنجندهى نـورى و رادارى استفادهشده است. منطقـهـ موردمطالعـه، بخشـى از شـهر شـيراز واقـع در جنوب ايران (شكل (1)) است. منطقـهـ انتخـابى شـامل
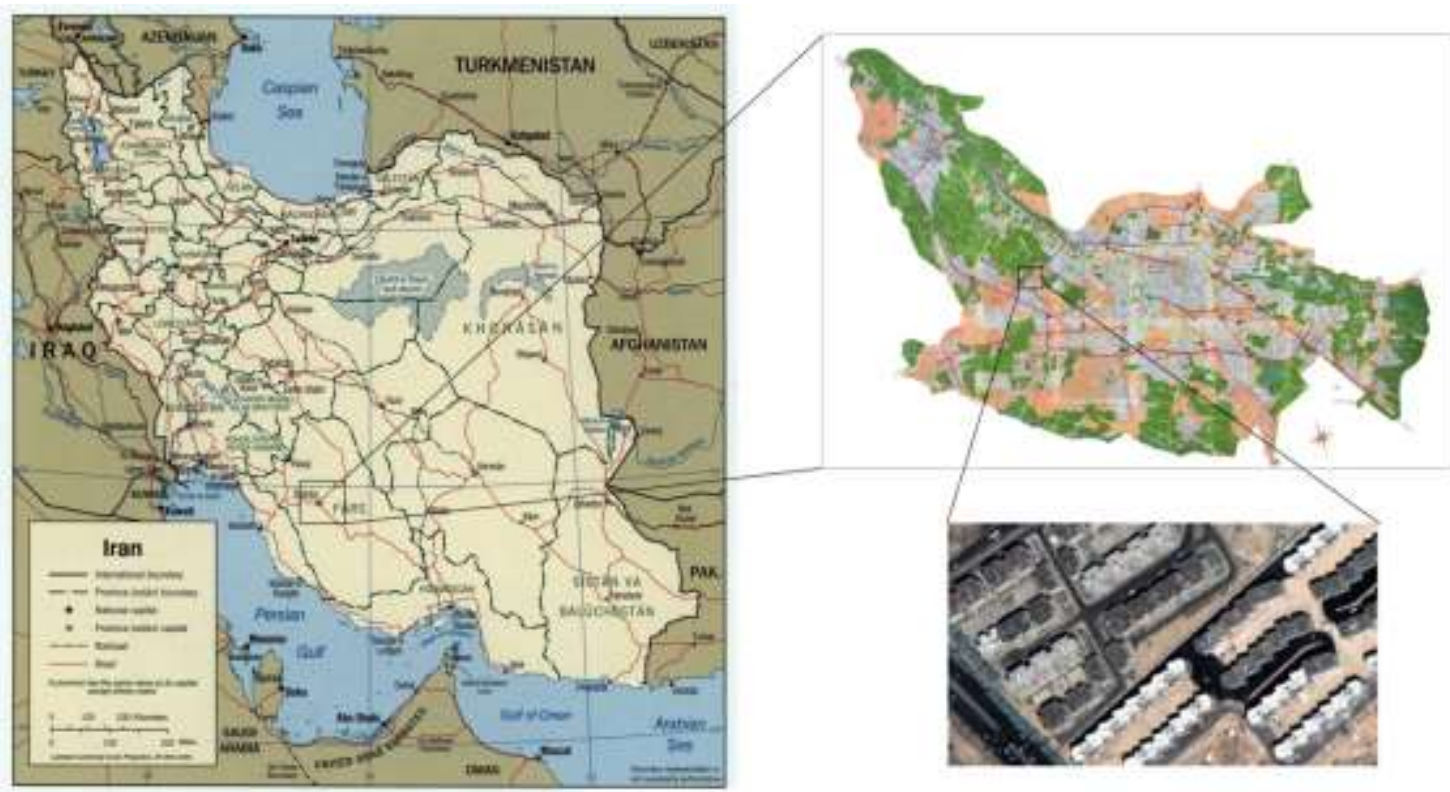

شكل ا: منطقه موردمطالعه، شهر شيراز

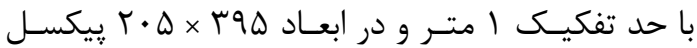

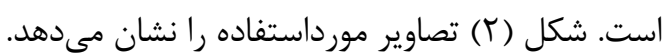

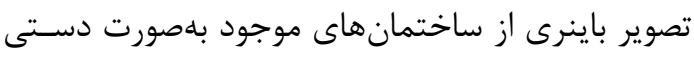

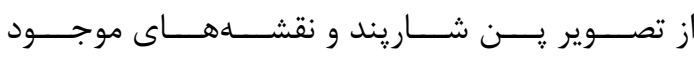

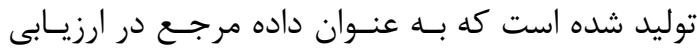

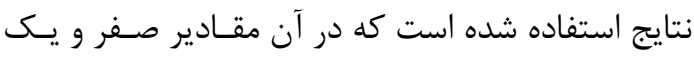

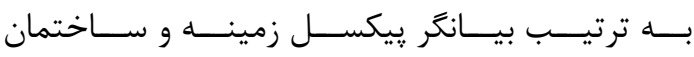

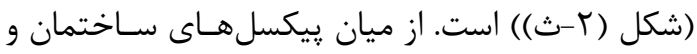

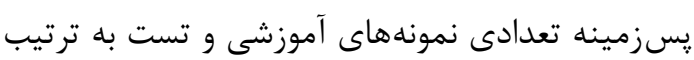

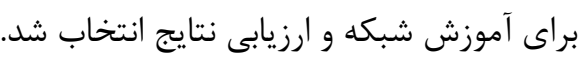

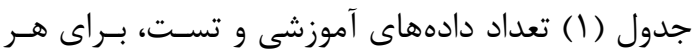
كلاس را نشان مى دهد. قابل ذكر است كه تمام يوشـش

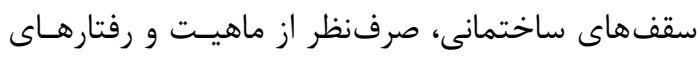
طيفىشان در كلاس ساختمان قراركرفتهاند.
تصـوير رادارى تراسـار -ايكسـس در مـد اســات لايست '

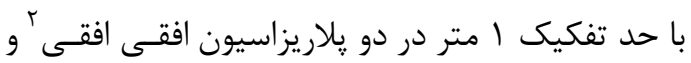

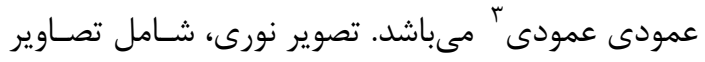

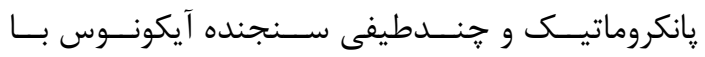

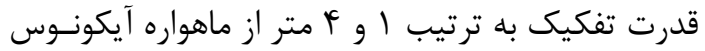

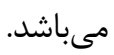
جهت همبعدسازى تصوير קنــدطيفى بـا ديخـــ تصـاوير

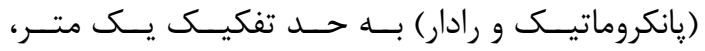

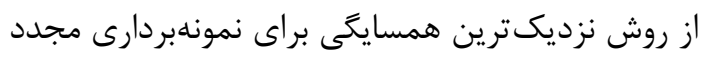

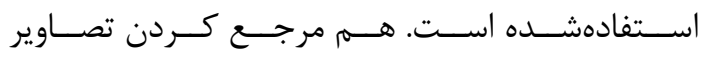
توسط II ا نقطه كنتـرل بـا ريشه ميانگَين مربعات خطا

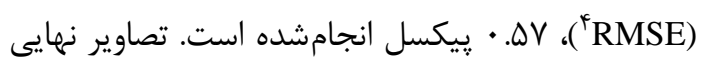

\footnotetext{
${ }^{1}$ Spotlight

$2 \mathrm{HH}$

$3 \mathrm{VV}$

4 Root Mean Square Error
} 


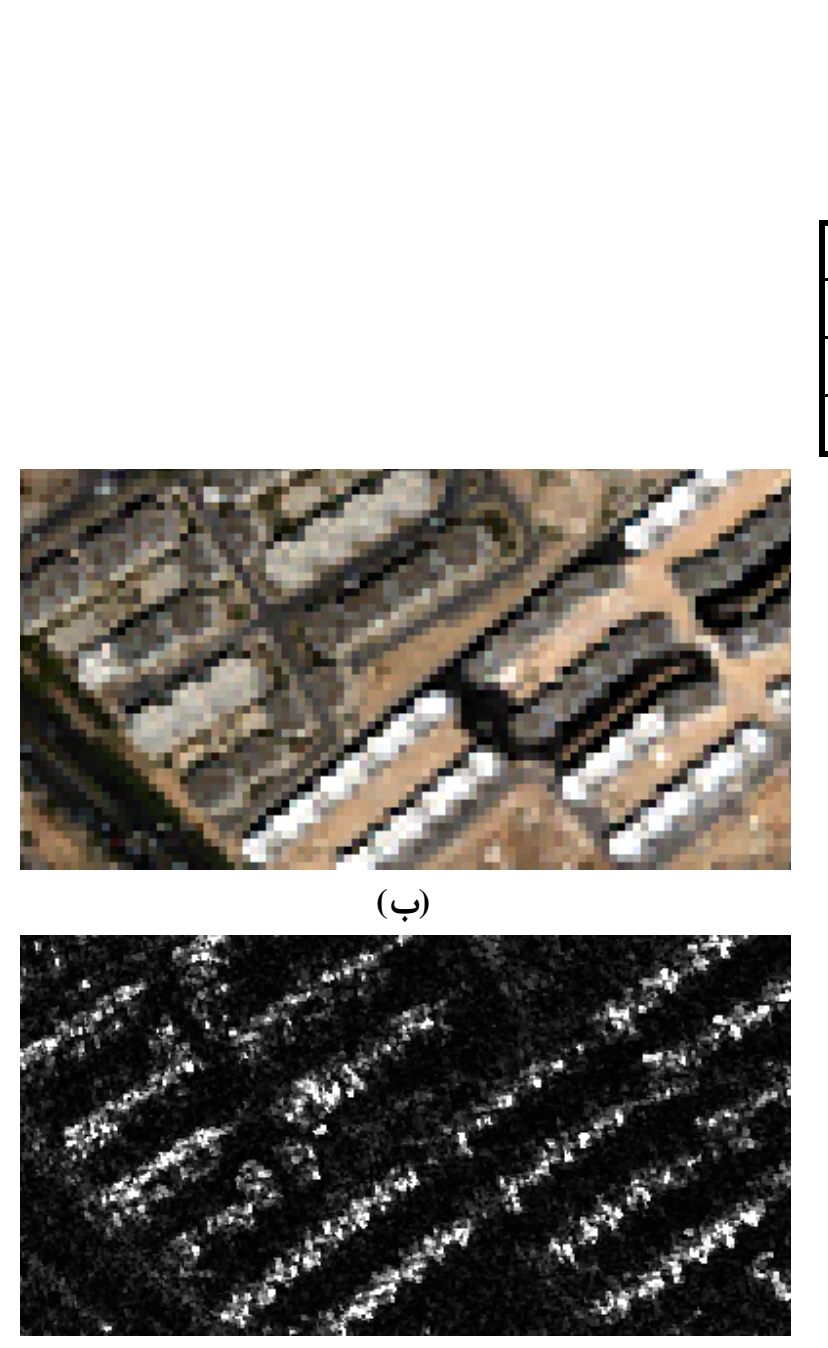

(ت)

\begin{tabular}{|c|c|c|}
\hline كلاس & داده آموزشى & داده تست \\
\hline ساختمان & IVT & 19TFT \\
\hline يس زمينه & 111 & GIVTr \\
\hline جمع نهايي & rar & $\Lambda \cdot 9 \vee \Delta$ \\
\hline
\end{tabular}

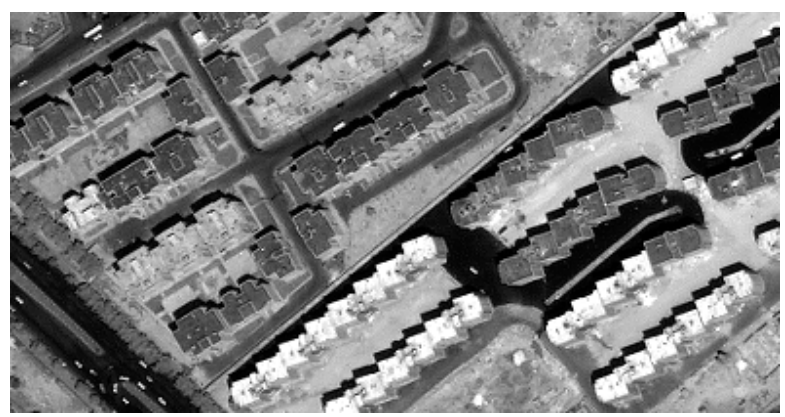

(الف)

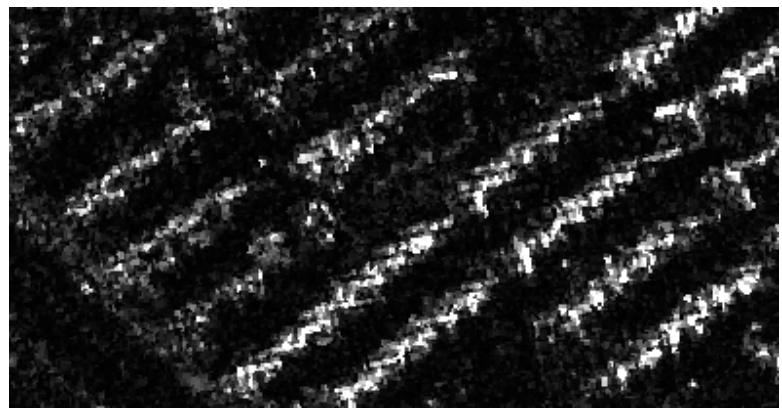

(»)

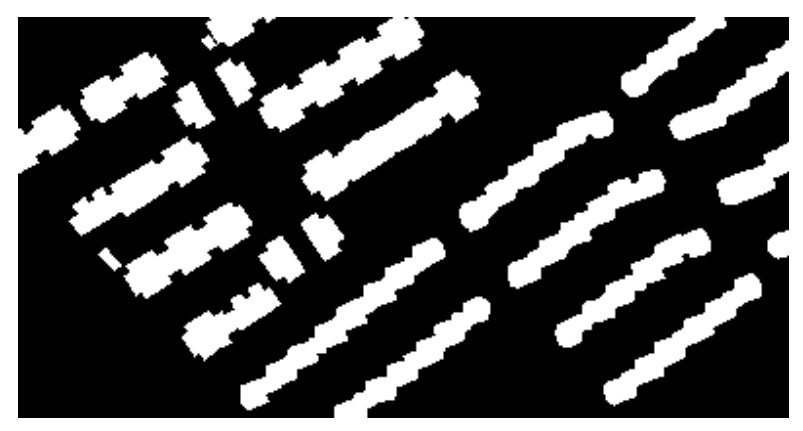

(ث)

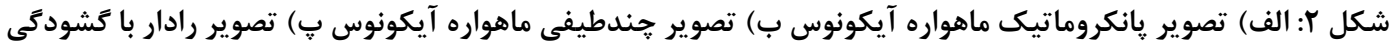

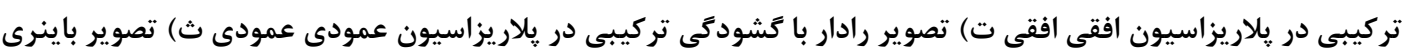
توليدشده جهت ارزيابى دقت

ويزگ هاى كوناكونى (جدول (r)) از تصاوير توليد شد.

سبس ويزگى هاى بهينه براى هر مجموعه داده از

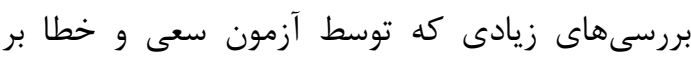

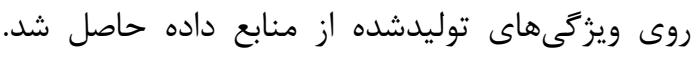

$$
\text { r- ب- روش تحقيق }
$$

در تحقيق حاضر، ابتدا از منابع مختلف داده شامل

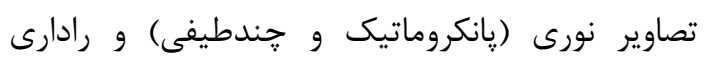

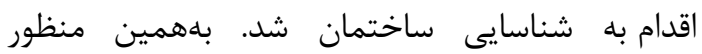


در جهت بهبود دقت و نتايج حاصل از شناسايى

سيس ويزَّى هاى بهينه وارد شبكه عصبى شد. سيس ساختمان اقدام به تلفيق تصاوير در سطح ويزگى شد.

ضمن تجزيهوتحليل نقاط ضعف و قوت هر مناي منبع، با استفاده از ويزگى هاى مكمل دادههاى نورى و رادارى

جدول r: ويزگكىهاى بهكاربرده شده در اين تحقيق

\begin{tabular}{|c|c|c|}
\hline دامنه داده & \multirow{5}{*}{ توصيفكر هاى آمارى مرتبه اول } & \multirow{14}{*}{ بافت } \\
\hline 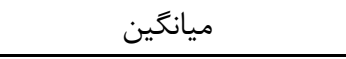 & & \\
\hline 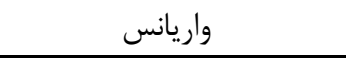 & & \\
\hline 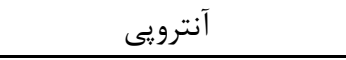 & & \\
\hline 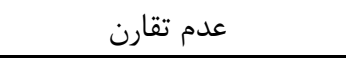 & & \\
\hline 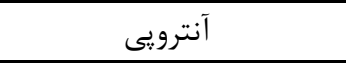 & \multirow{8}{*}{ توصيفكَرهاى آمارى مرتبه دوم } & \\
\hline 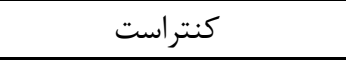 & & \\
\hline 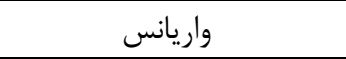 & & \\
\hline 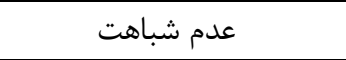 & & \\
\hline همخنى & & \\
\hline ميانگَين & & \\
\hline مان مرتبه دوم & & \\
\hline همبستىى & & \\
\hline 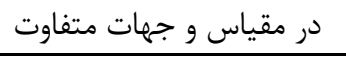 & فيلتر كابور & \\
\hline هيلاريزاسيون افقى افقى & \multirow{2}{*}{\multicolumn{2}{|c|}{ ير براكندى دوكانه }} \\
\hline يلاريزاسيون عمودى عمودى & & \\
\hline ليلاريزاسيون افقى افقى & \multirow{2}{*}{\multicolumn{2}{|c|}{ دامنه تصوير رادار با گشودگى تركيبى }} \\
\hline 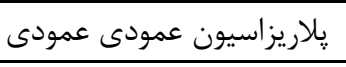 & & \\
\hline \multicolumn{3}{|c|}{ اطلاعات طيفى f باند (قرمز، آبى، سبز، مادونقرمز نزديك) تصوير جندطيفى } \\
\hline اتيك & 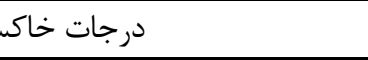 & \\
\hline
\end{tabular}

جهت شناسايى ساختمان است. در اين راستا بهمنظـور داشتن يك شبكه عصبى بهينه، تعيـين مناسـب تعـداد

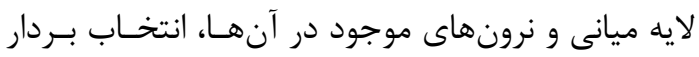

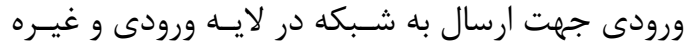
موردنياز است. بر طبق تحقيقات صورت كرفتـه توسـط الـاه

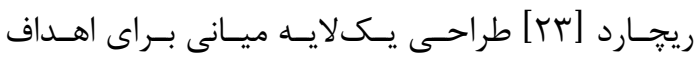

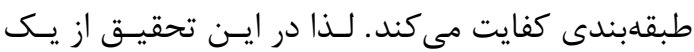

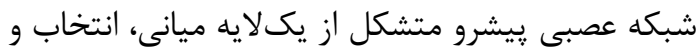

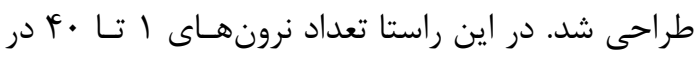

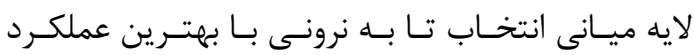

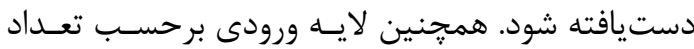

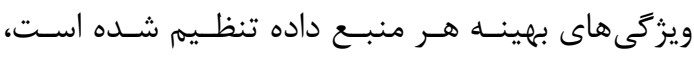

در تمام اسـتراتزىهـاى شناسـايى سـاختمان در ايـن

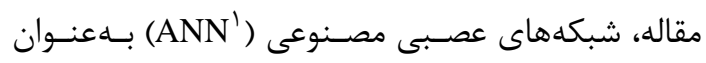
يك طبقلبندى كننده دو كلاسـه اسـتفاده شـده اسـت. ويزگى اصلى شبكه عصبى قابليـت يـذيرش و يــردازش دادههاى ورودى غير متجانس و داراى اهميـت متفــاوت

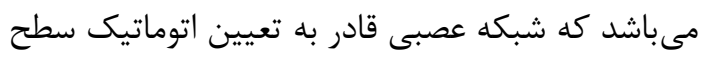

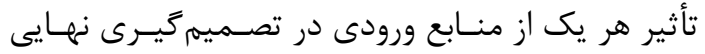

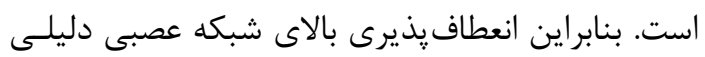

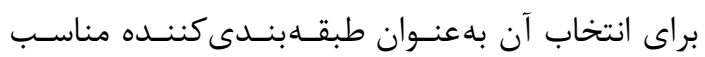

${ }^{1}$ Artificial Neural Network 
عهدهدارند. شكل (؟) سـاختار شـبكه عصـبى بـا هـدف

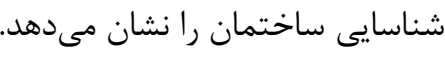

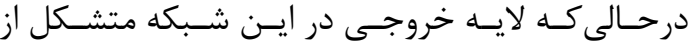

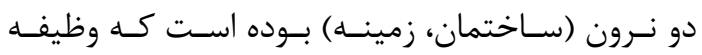

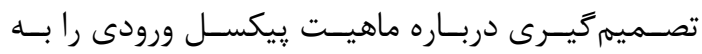

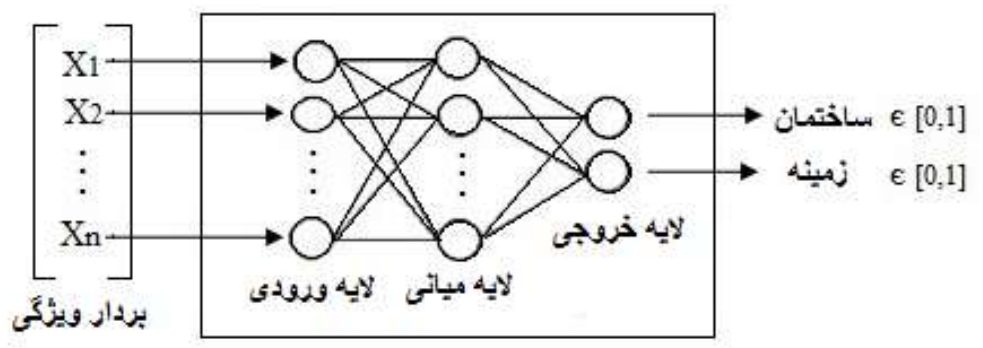

شكل זّ: ساختار شبكه عصبى باهدف شناسايى ساختمان

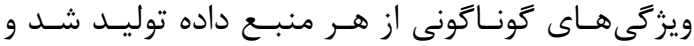

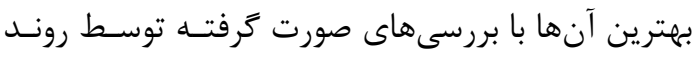

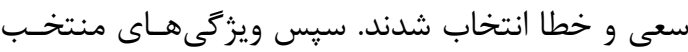
به شبكه عصبى معرفى شدند و تعداد نرون حها در لايسها

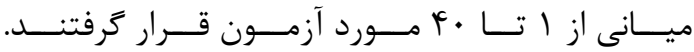

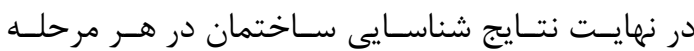

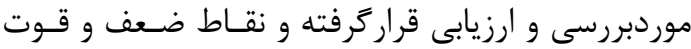

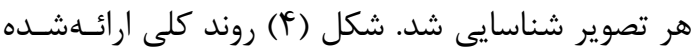
را نشان مى دهد.

\section{r-1-1-تصوير يانكروماتيك}

به دليل كمبود اطلاعات طيفى اين تصوير، از اطلاعـات باند يانكروماتيك و بافت استفاده شده است. آناليز بافت آت التهات يكى از رايجترين روشهاى ايجاد توصيفكرهاى عـوارض سطحى در تصاوير رقومى است كه مسىتوانـد بـهـعنـوان معيارى جهت تمايز بين اشياء مختلف موجود در تصوير

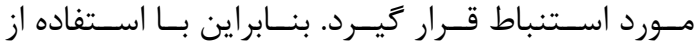

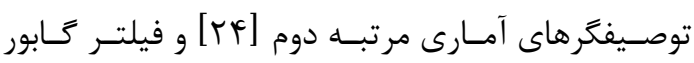

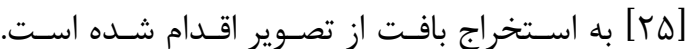
استفاده از توصيفكرهاى آمارى مرتبه دوم در اسـتخراج

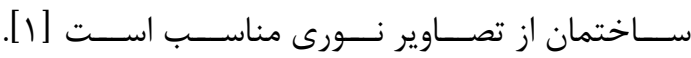
توصيفكرهاى آمارى مرتبه دوم، علاوه بر در نظر كرفتن توزيع درجات خاكسترى، موقعيت يريكسلها نسـبت بــهـ يكديكر را نيز لحاظ مى كنند.

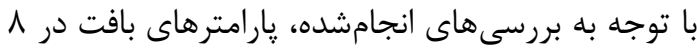

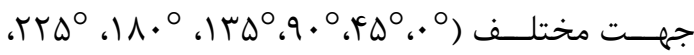

جهت ارزيابى نتايج، سه معيار دقت كلى، ضريب كايـاو

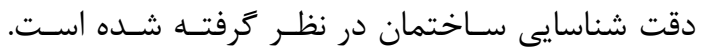

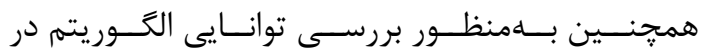

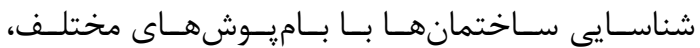

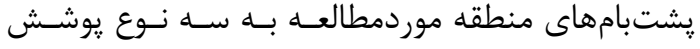

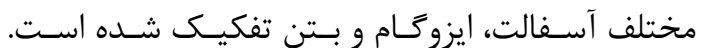
در اين راستا انحراف معيـار دقـت شناسـايى سـاختمان

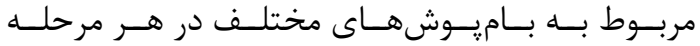

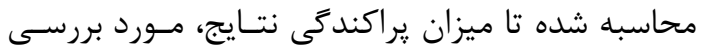

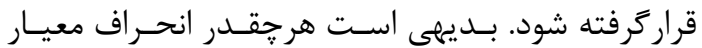
مربوطه كمتر باشد، مؤيد عملكرد همخـن تـر الحَــوريته بر روى منطقه و مطلوبتر است.

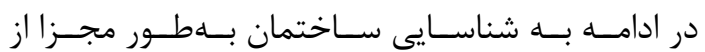

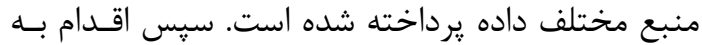

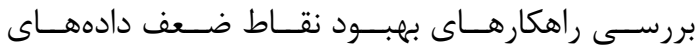
مستقل شده است. در اين راستا ابتدا هر يك از تصـاوير

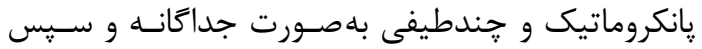
يكجا با تصوير رادار در سطح ويزگى تلفيقشدهاند.

r-1- استفاده مجزا از تصاوير نورى و رادارى در الكوريتمهــاى مبتنسى بــر ويزّكى لازم اسـت كـهـ از

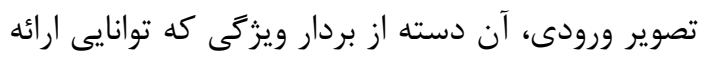
خصلتحهاى تصوير را داشته باشند استخراج و ســــ آنس

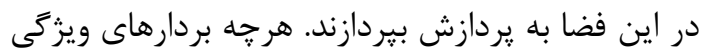
مستخرج از تصوير كارايى بهتـرى داشـــه باشــند بـازده

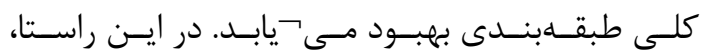


شناسايى ساختمان در مناطق شهرى با استفاده از تلفيق....

مريم تيمورى، مهدى مختارز اده و محمدجواد ولدان زوج

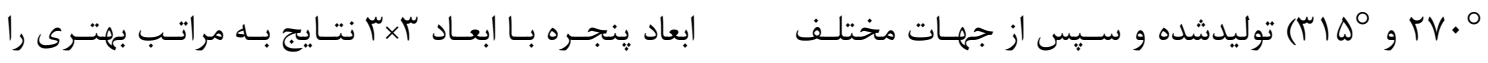

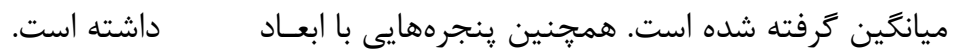

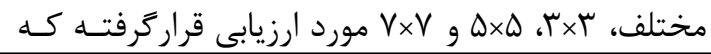

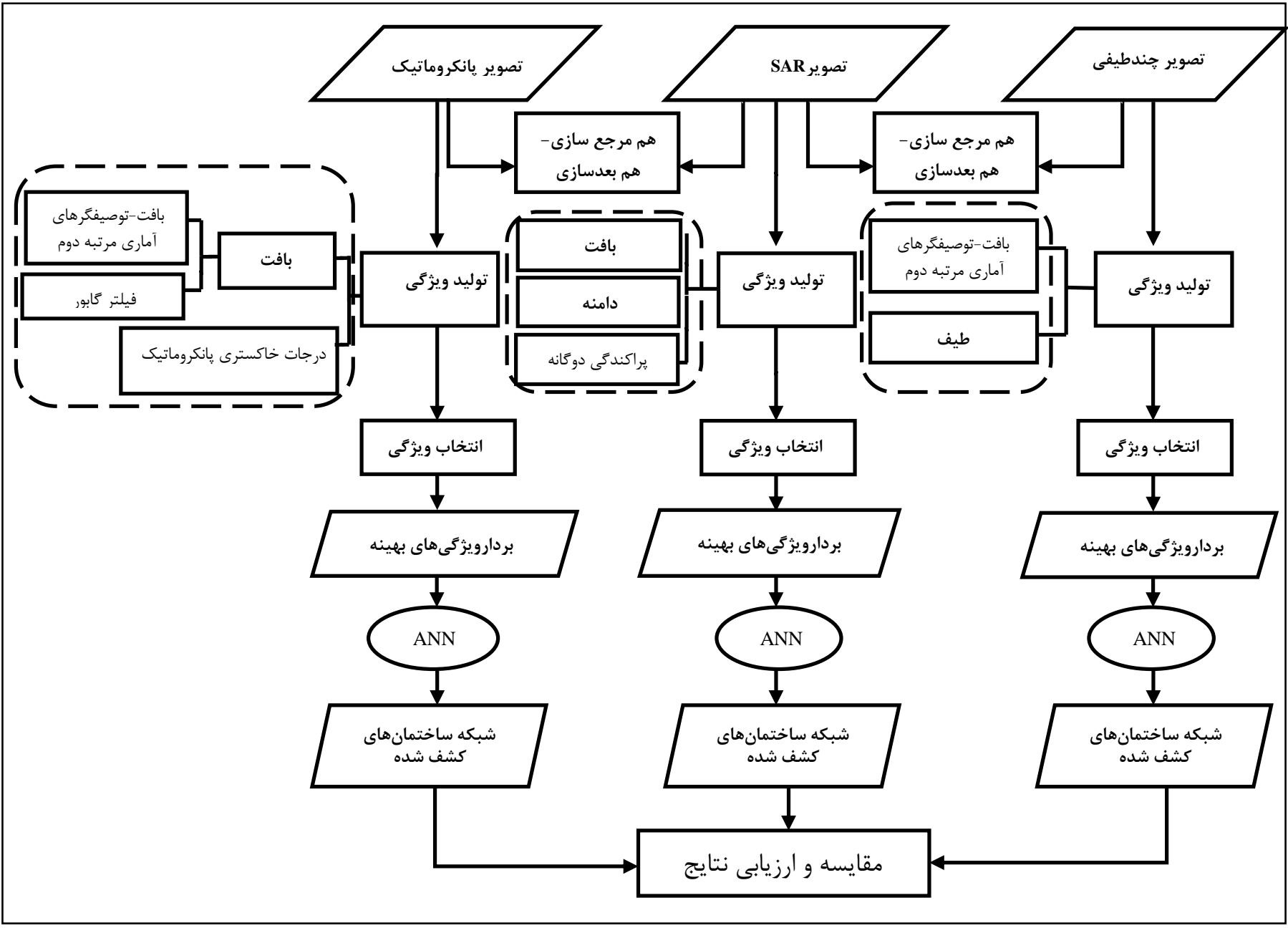

شكل f: روند كلى بررسى جداكانه تصاوير

انتخاب شده است.

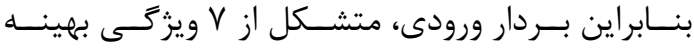
(درجات خاكسترى باند يانكروماتيـك، ه هـارامتر فيلتـــ

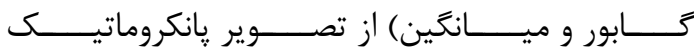

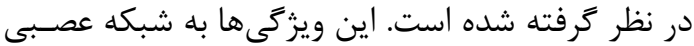

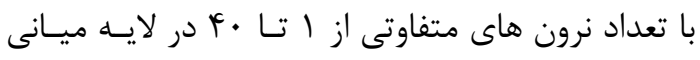

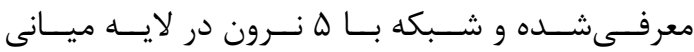

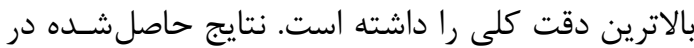
جدول (Гآ) نشان دادهشده است.

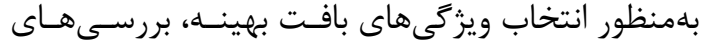

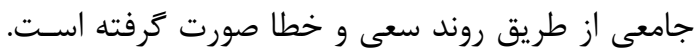

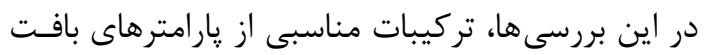

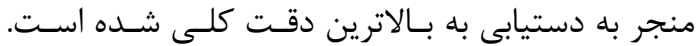

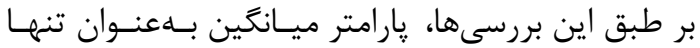

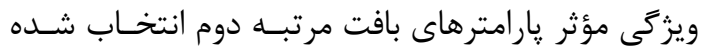
است. همجنين يارامترهاى فيلتـر كَابور تــأثير بسـزايى داشته است، در اين راستا فيلتر كابور در هـ مقياس و دراس در

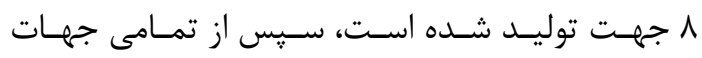

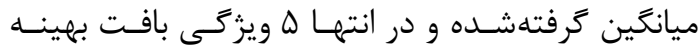


جدول بّ: يارامترهاى ارزيابى الكوريتم شناسايى ساختمان مربوط به تصوير يانكروماتيك

\begin{tabular}{|c|c|c|c|c|c|c|}
\hline \multirow{2}{*}{ بردار ويزگى بهينه } & \multicolumn{3}{|c|}{ دقت شناسايى يوششها } & \multirow{2}{*}{ كلى } & \multirow{2}{*}{ ضريب كايا } & \multirow{2}{*}{ دقت شناسايى } \\
\hline & آسفالت & ايزوكام & بتن & & & \\
\hline 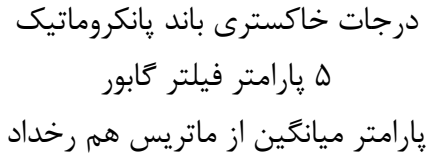 & $\Delta V . V I$ & 91.19 & 1.90 & $\vee 9$ & rq.v & $Q \cdot . r \Lambda$ \\
\hline
\end{tabular}

را داشتهاند. بنابراين اين دو ويزّكى در ينجرهاى با ابعـاد

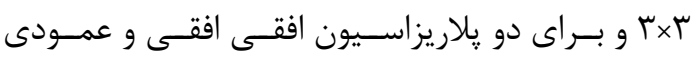

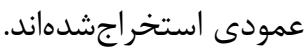

اثر يراكندگى دو خانه بهعنوان ويزگى مفيد استخراجشده

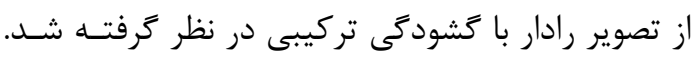

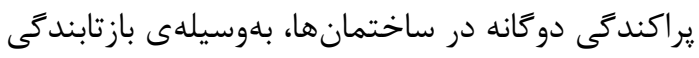

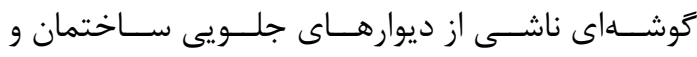

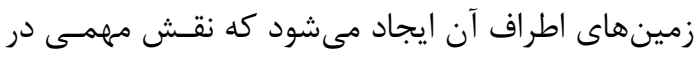

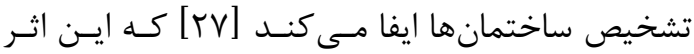

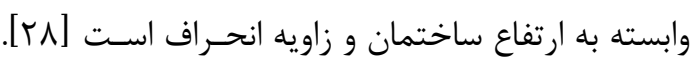

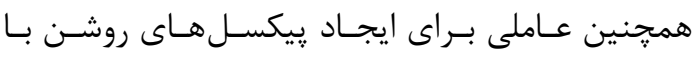

$$
\text { دامنه بزرى در تصوير مىباشد. }
$$

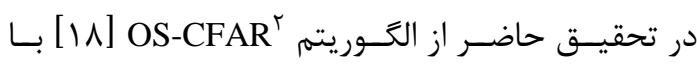

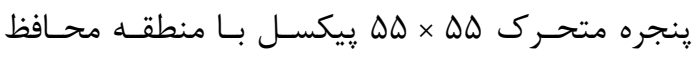

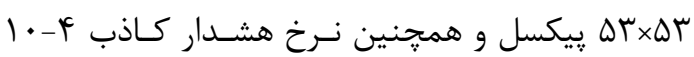

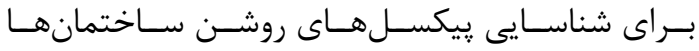

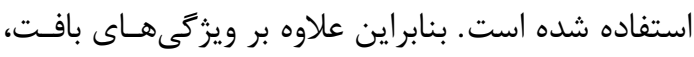

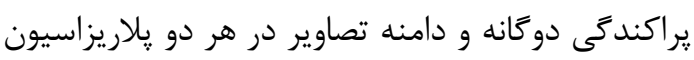
بلهنوان ويزگكىهاى ورودى در نظر ترفته شدند.

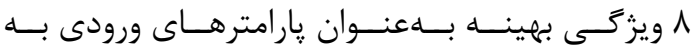

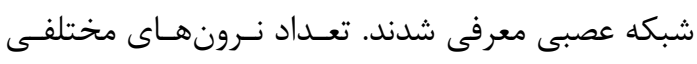

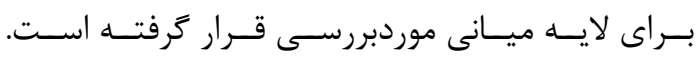

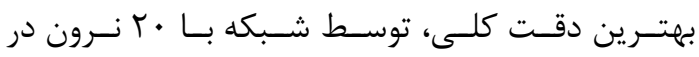

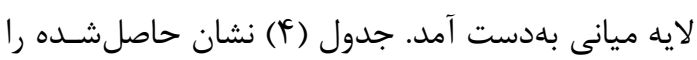

$$
\text { نشان مى نهد. }
$$

\footnotetext{
${ }^{2}$ Order Statistics -Constant False Alarm Rate
}

همــانطــور كــه از جــدول بــالا و شـكل (ه- الــف)

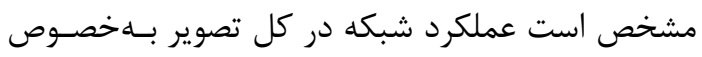
در ريشتبامهايى از جنس بتن بسيار ضعيف بوده و تنهـا

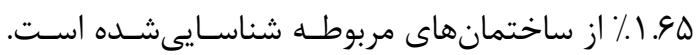

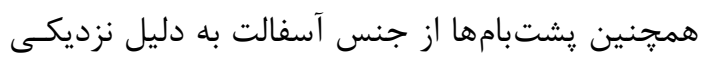

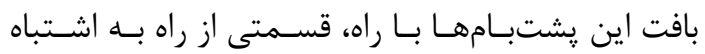
ساختمان شناسايى شده است، بنابراين شبكه عصـبى در اين ناحيه عملكرد مناسبى نداشته است. انحراف معيـار

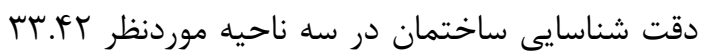

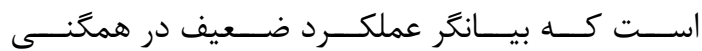
نتايج مىباشد.

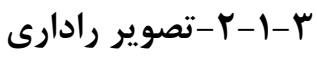
تفسير عوارض سطح زمين در تصاوير رادارى بر اسـاس

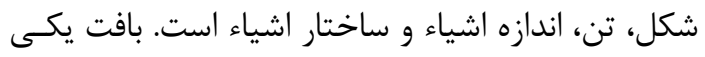

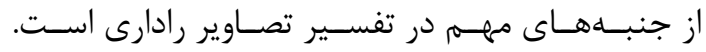

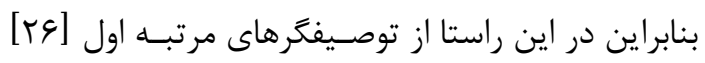
در تصوير تراسار -ايكس استفادهده است. توصيفكَرهاى مرتبه اول بر اساس هيسـتوكرام تصـوير و

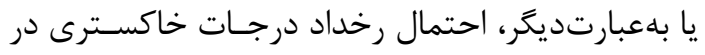

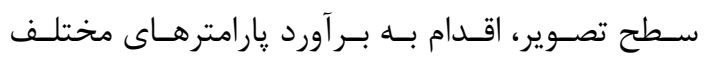

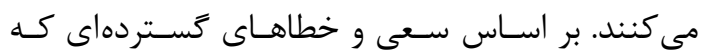
بر روى يارامترهاى بافت و در ابعاد ينجرههـاى مختلـف

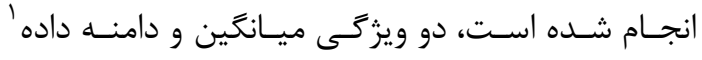

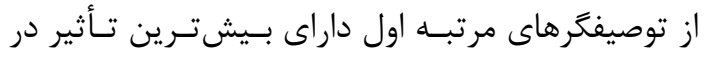

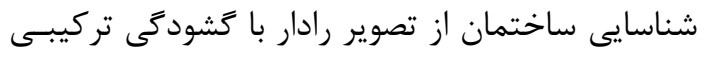

\footnotetext{
${ }^{1}$ data range
} 
شناسايى ساختمان در مناطق شهرى با استفاده از تلفيق...

مريمم تيمورى، مهدى مختارز اده و محمدجواد ولدان زوج

جدول f: بارامترهاى ارزيابى الكوريتم شناسايى ساختمان مربوط به تصوير رادار

\begin{tabular}{|c|c|c|c|c|c|c|}
\hline \multirow{2}{*}{ بردار ويزَى بهينه } & \multicolumn{3}{|c|}{ دقت شناسايى يوششها } & \multirow{2}{*}{ دقت } & \multirow{2}{*}{ ضريب } & \multirow{2}{*}{ دقت شناسايى } \\
\hline & آسفالت & ايزوَام & بتن & & & \\
\hline 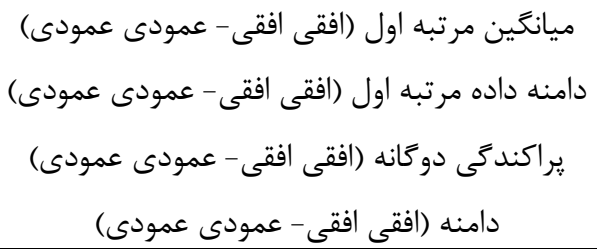 & GV.T. & 19.90 & $\Delta \wedge .10$ & NT.IT & $\Delta \Delta . g Y$ & VI.VA \\
\hline
\end{tabular}

مــباشــند. امـا اسـتفاده تنهــا از اطلاعــات طيفـى در طبقهبندى عوارض در مناطق شهرى به دليـل شـباهت

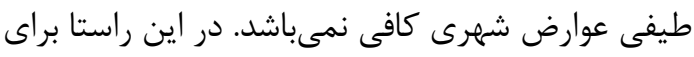

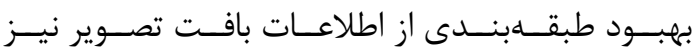

استفاده شد.

بهمنظور انتخاب پارامترهاى بافت مناسب تعداد وسيعى

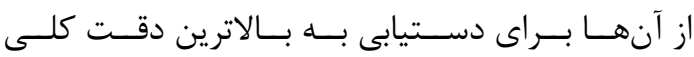
مورد آزمايش قرار گرفت. در اين بررسى ها، يارامترهـاى ميانگين و واريانس از توصـيفگرهاى آمـارى مرتبـهـ دوم

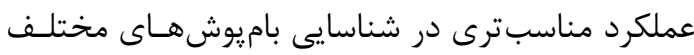

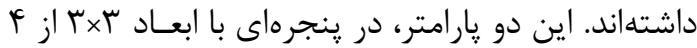

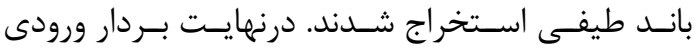

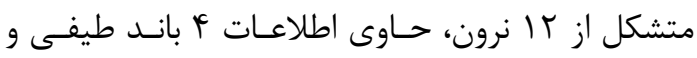

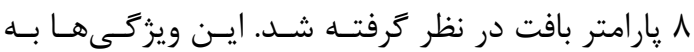

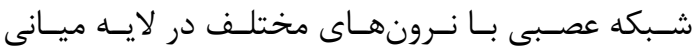
واردشده و درنهايت V نرون بهعنوان نرون بهينه در لايه

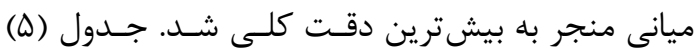
نتايج بلهدست آمده را نشان مى بـهد.
از مقايســـه يارامترهـــاى ارزيــابى در جـــدول (ب و أ)

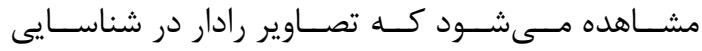
سـاختمانهــا نسـبت بــه تصـوير رانكروماتيـك توانــاتر بوده است. با اينكه در باميوشهـاى بتنـى تصـوير رادار

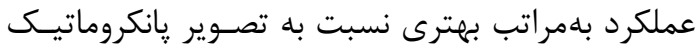

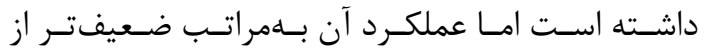
باميوشهاى ديخر است. بالين حال اسـتفاده از دادههـاى رادار باعث همگَنى بيشتر ياسخهـا در نـواحى مختلـف

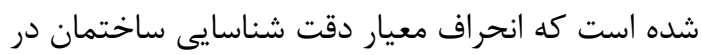

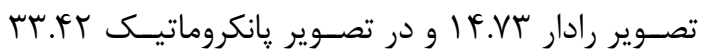

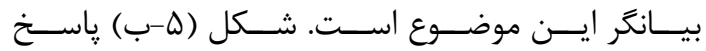
شبكه عصبى را نشان مى دهد و همانطور كـهـ از شـكل

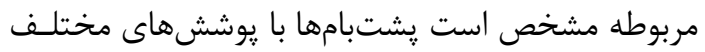

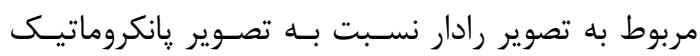
عملكرد بهترى داشته است. r-1-r-r تصوير קندطيفى اطلاعات طيفى، جهار باند تصوير آيكونوس استفاده شد كه حاوى اطلاعات مفيدى جهـت شناسـايى سـاختمان

جدول ه: يارامترهاى ارزيابى الكَوريتم شناسايى ساختمان مربوط به تصوير جندطيفى

\begin{tabular}{|c|c|c|c|c|c|c|}
\hline \multirow{2}{*}{ بردار ويزگى بهينه } & \multicolumn{3}{|c|}{ دقت شناسايى يوششها } & \multirow{2}{*}{ دقت } & \multirow{2}{*}{ ضريب } & \multirow{2}{*}{ دقت شناسايى } \\
\hline & آسفالت & ايزوكام & بتن & & & \\
\hline 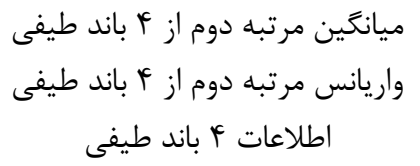 & $\vee \Delta . V q$ & $91.4 F$ & $\wedge \vee . \& \wedge$ & $\Lambda r .\left.\right|^{f}$ & $\Delta \wedge . \Delta r$ & NT.ru \\
\hline
\end{tabular}


نسبت به ياسخ تصوير پانكروماتيك و رادار كه به ترتيب

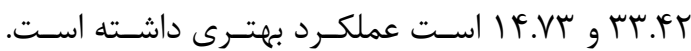
همانطور كه از شكل (ब-ب) مشاهده مى گَردد ياسـخ خروجى اين مرحله نيز مانند ياسخ شبكه عصبى تصوير يانكروماتيك در تفكيك برخى راهها از يشتبامها ناتوان بوده است، پِ مى توان نتيجه كَرفت بافت برخى راههــا

در تصاوير نورى مشابه با بافت يشتبامها است.
همانطور كه نتايج حاصل از ياسخ شبكه عصـبى بـراى

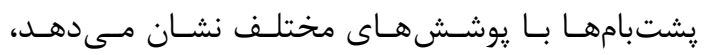

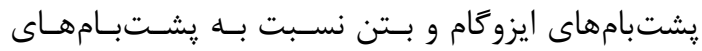
آسفالت عملكرد مناسبىترى داشتهاند. بنابر اين مى توان

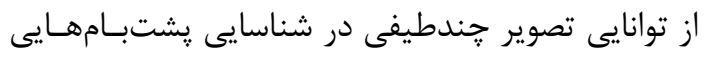
از جنس بتن، در تلفيق تصاوير سود برد. انحراف معيـار دقت شناسايى ساختمان در اين تصوير 1V.IV است كـهـ

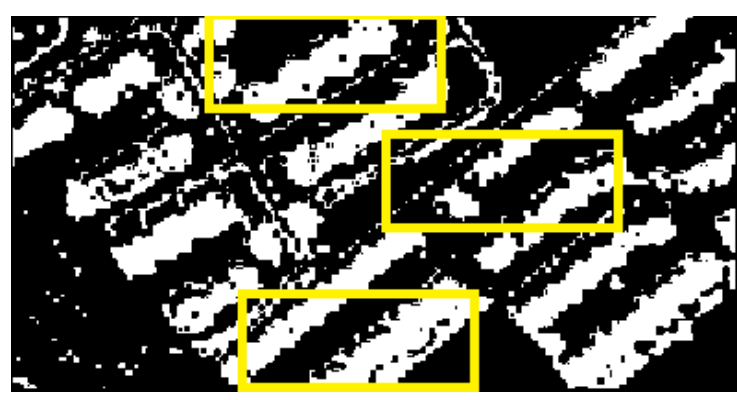

(ب)

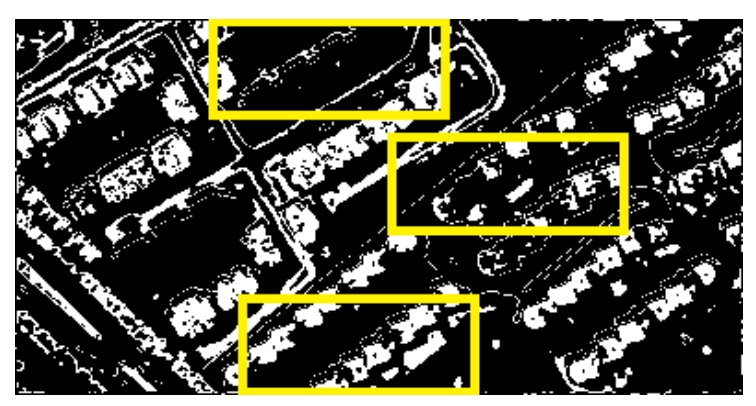

(الف)

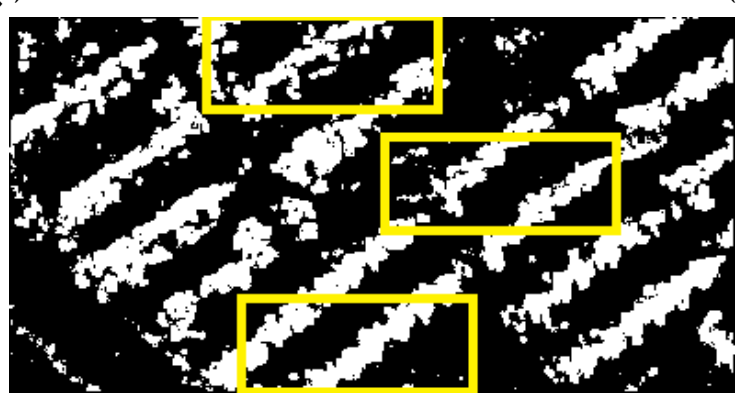

(ب)

شكل ه: پاسخ شبكه عصبى الف: تصوير پانكروماتيك ب: تصوير رادار ب: جندطيفى

r-r-1-تلفيق تصاوير پانكروماتيك و رادار

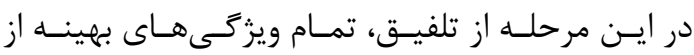

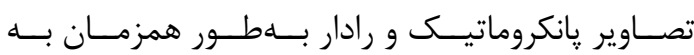

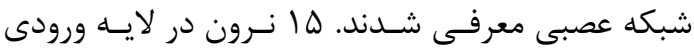

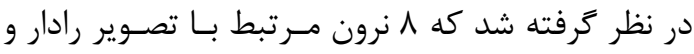

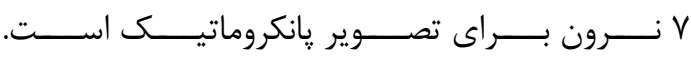
با بررسى هاى صورت كرفتـه، وب نـرون در لايـه ميـانى

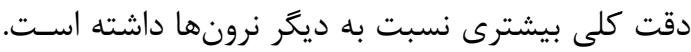

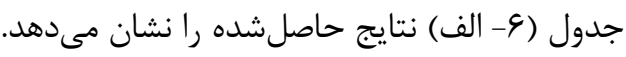

r-r- تلفيق در سطح ويزگى تلفيق در سطح ويزگى، نيازمند استخراج ويزگى مناسب

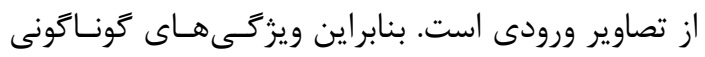

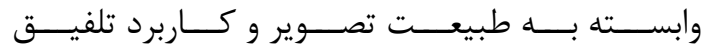

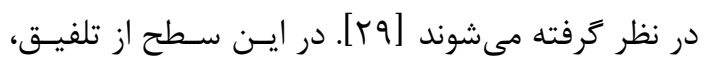

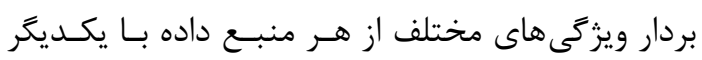

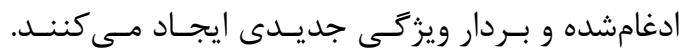

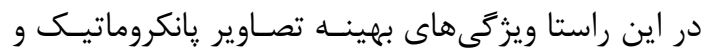

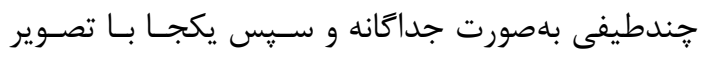

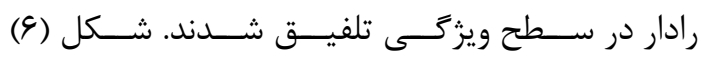
روند اجرايى كلى اين مراحل را نشان مىدهد. 
شناسايى ساختمان در مناطق شهرى با استفاده از تلفيق...

مريم تيمورى، مهدى مختارز اده و محمدجواد ولدان زوج

جدول \&: يارامترهاى ارزيابى الكوريتم تلفيق در سطح ويزَىى

\begin{tabular}{|c|c|c|c|c|c|c|c|c|c|}
\hline & & \multirow{2}{*}{ بردار ويزگى هاى بهينه } & \multirow{2}{*}{ مر لايه } & \multicolumn{3}{|c|}{ دقت شناسايى يوششها } & \multirow{2}{*}{ دلى } & \multirow{2}{*}{ 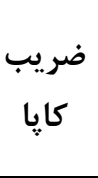 } & \multirow{2}{*}{ شاختاسايى } \\
\hline & & & & آسفالت & ايزوگام & بتن 1 & & & \\
\hline \multirow[b]{2}{*}{ الف الف } & קֶانكروماتيك & درجات خاكسترى باند يانكروماتيك،ه هارامتر & \multirow[b]{2}{*}{ rq } & \multirow[b]{2}{*}{99.09} & \multirow[b]{2}{*}{$9 r .10$} & \multirow[b]{2}{*}{$\Delta D . r V$} & \multirow[b]{2}{*}{$\wedge \Delta . \vee \Delta$} & \multirow[b]{2}{*}{91.19} & \multirow[b]{2}{*}{$V^{f} . \Delta \cdot$} \\
\hline & رادار & 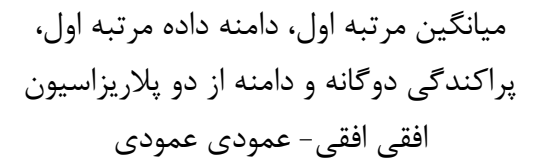 & & & & & & & \\
\hline \multirow[b]{2}{*}{ ب } & جندطيفى & 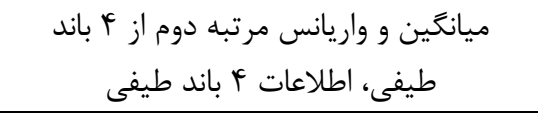 & \multirow[b]{2}{*}{ r. } & \multirow[b]{2}{*}{$\wedge r .9 \vee$} & \multirow[b]{2}{*}{$9 \Delta . \digamma \wedge$} & \multirow[b]{2}{*}{$9 Y . Y 1$} & \multirow[b]{2}{*}{ AG.YY } & \multirow[b]{2}{*}{99.14} & \multirow[b]{2}{*}{$\Lambda \Lambda . I \vee$} \\
\hline & رادار & 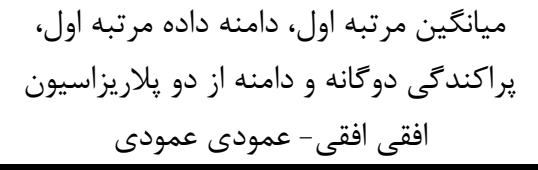 & & & & & & & \\
\hline \multirow{3}{*}{ 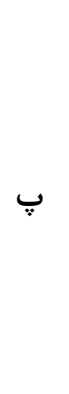 } & يانكروماتيك & 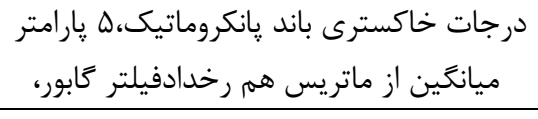 & \multirow{3}{*}{ r. } & \multirow{3}{*}{$\wedge 9 . \cdot \Delta$} & \multirow{3}{*}{19.19} & \multirow{3}{*}{$\wedge \vee .91$} & \multirow{3}{*}{ AV.II } & \multirow{3}{*}{$9 \vee .99$} & \multirow{3}{*}{$\wedge 9 . \cdot 1$} \\
\hline & ر & 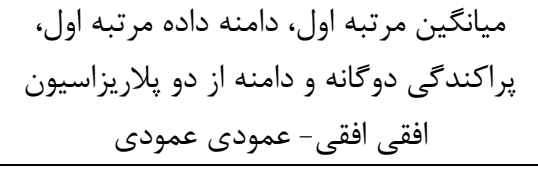 & & & & & & & \\
\hline & ֶندطيفى & 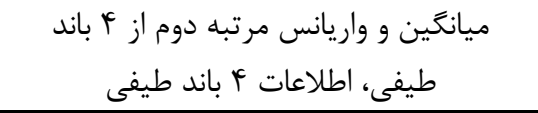 & & & & & & & \\
\hline
\end{tabular}

مرتبط با ويزخى هـاى بهينــه تصـوير קنــدطيفى اسـت.

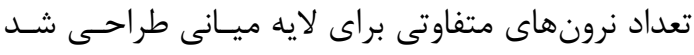

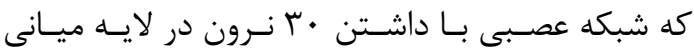
داراى عملكــرد بهتـــى بـوده اســت. نتــايج حاصــل از تلفيق اين دو تصوير در جدول (و-ب) آورده شده است.

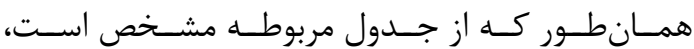

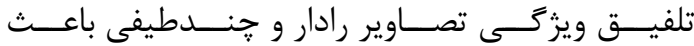
افزايش دقت در تمامى يارامترهـاى ارزيـابى نسـبت بــهـ

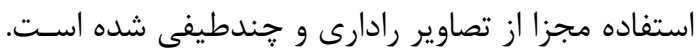

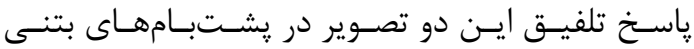
عملكرد بسيار مناسبى از خود نشان داده اسـت. ميـزان

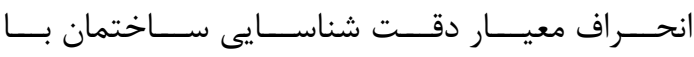
يوششهاى مختلف نيز برابر با باه.9 است.
همانطور كه در جدول (9-الف) نشان دادهشـده اسـت

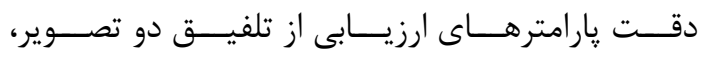
بهبود هشمگيرى در تمامى پارامترها نسبت به استفاده مجزا از دو تصـوير (يانكروماتيـك، رادار) داشـته اسـت. بااينوجود، هنوز در شناسايى يشتبامهاى بتنى ضـف

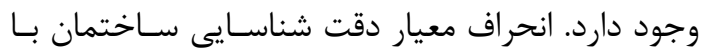
يوشش هاى مختلف س 19.1 است كـه دليـل بـالا بـودن انحراف معيار، اختلاف زياد دقت شناسايى يشتبامهـاى بتنى نسبت به يشتبامهاى ايزوكام و آسفالت است. r-r-r-r-r بهمنظور تلفيق اين تصاوير، ويزگى هاى بهينه از تصـاوير رادارى و جندطيفى همزمان وارد شبكه عصـبى شـدند. تعـداد نـرونهـاى بـردار ورودى شـــكه عصــبى شـامل

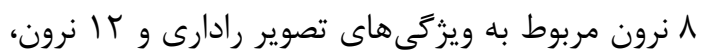


در برطرف كردن ضعف هر يـك از تصـاوير تـا حسدودى

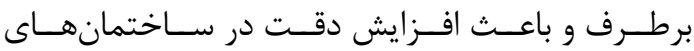

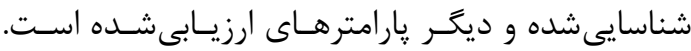

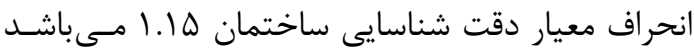

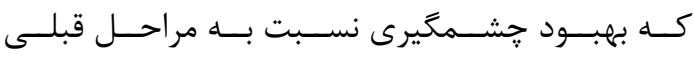

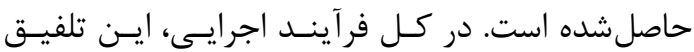

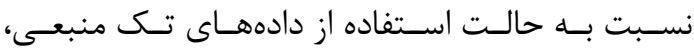
حداقل ^ برابر بهبود در انحراف معيار دقت ساختمان را

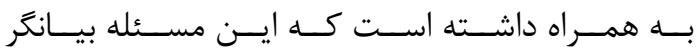
همگنتر شدن نتايج حاصلشده در يوشش هاى مختلف يشتبامهاى موردبر رسى است. لذا اين تلفيق بــهعنـوان

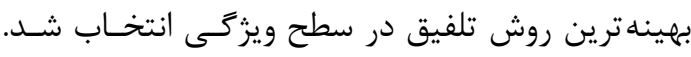

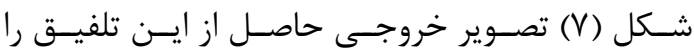

$$
\text { نشان مى دهد. }
$$

r-r-r-r-r r-r

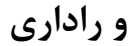

در ايـن مرحلـهـ از تلفيـق كليـهـ ويزخَى هــاى بهينــه از

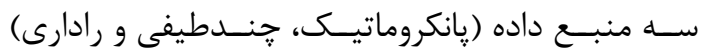

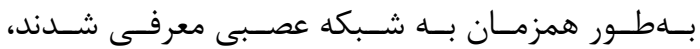

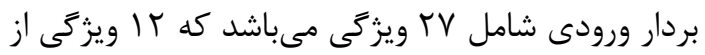

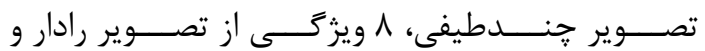

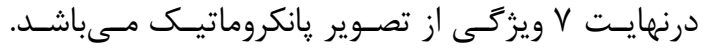

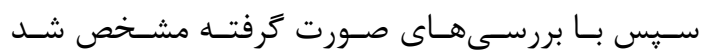

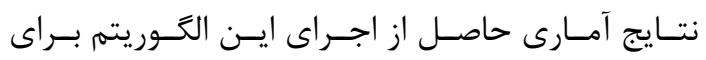

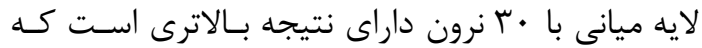
در جدول (צ-ب) آورده شده است.

نتايج ارائهشده در جــدول (ه-״) نشـان مسى دهـد كـهـ

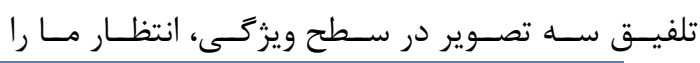

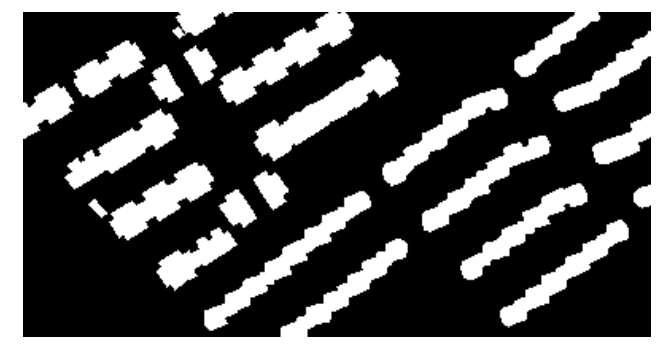

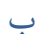

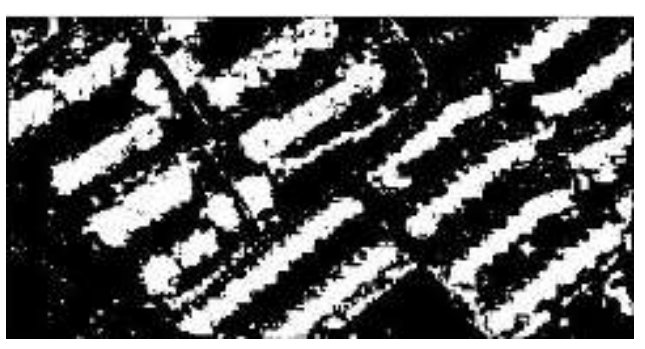

الف

شكل V: الف) ياسخ شبكه عصبى از تلفيق در سطح ويزگى تصاوير نورى و رادارى ب: تصوير باينرى توليدشده

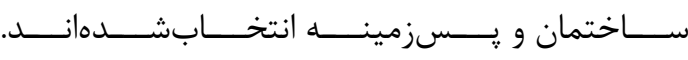
تمامى الخوريتمهاى تلفيقى بر اين منطقه بهطور مجدين

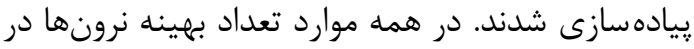

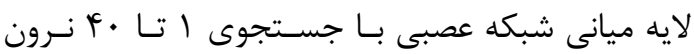

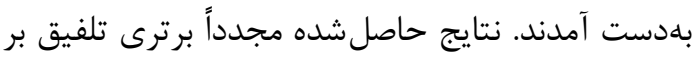

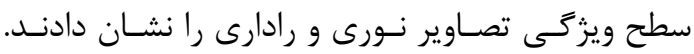
جدول (V) نتايج بلهدست آمده را نشان مى دهويد.
بهمنظور ارزيابى روش تلفيقى ييشنهادى بر منطقهاى

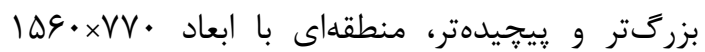

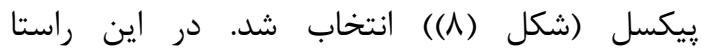

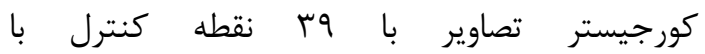
ريشه ميانگين مربعات خطا ، ه ه. · ريكسل انجام شد.

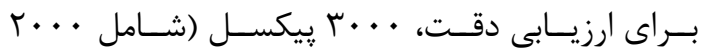

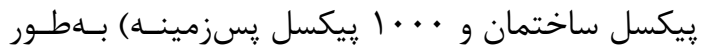

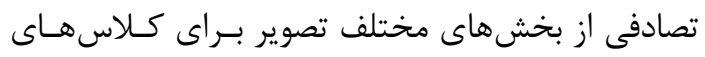


شناسايى ساختمان در مناطق شهرى با استفاده از تلفيق... مريم تيمورى، مهدى مختارزاده و محمدجواد ولدان زوج
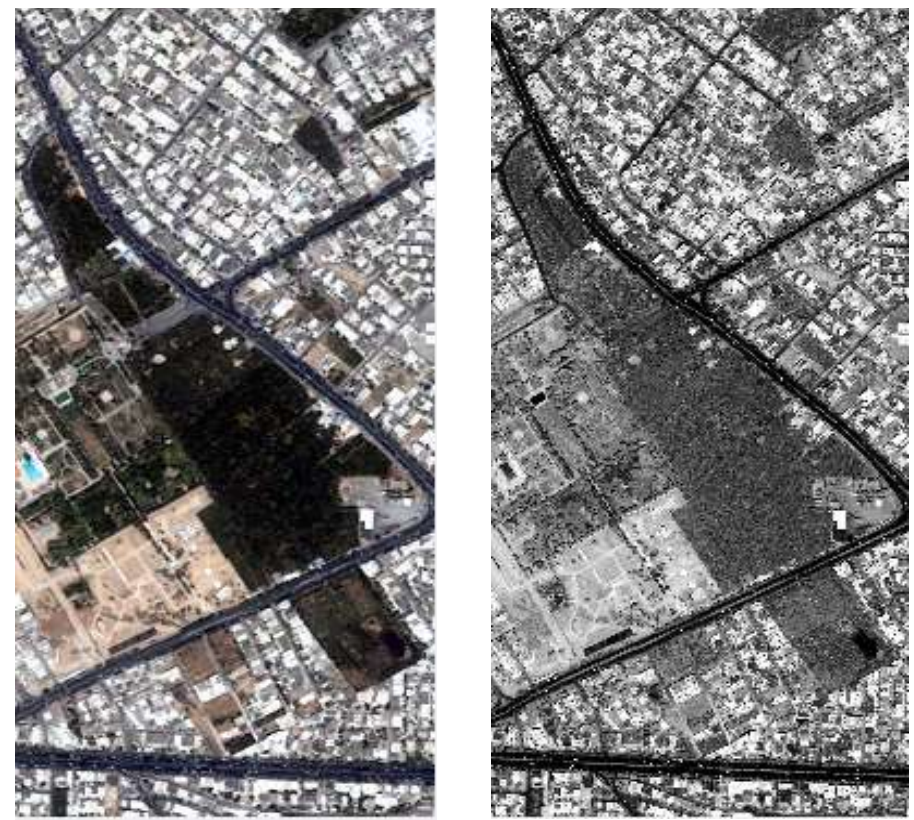

(ب)

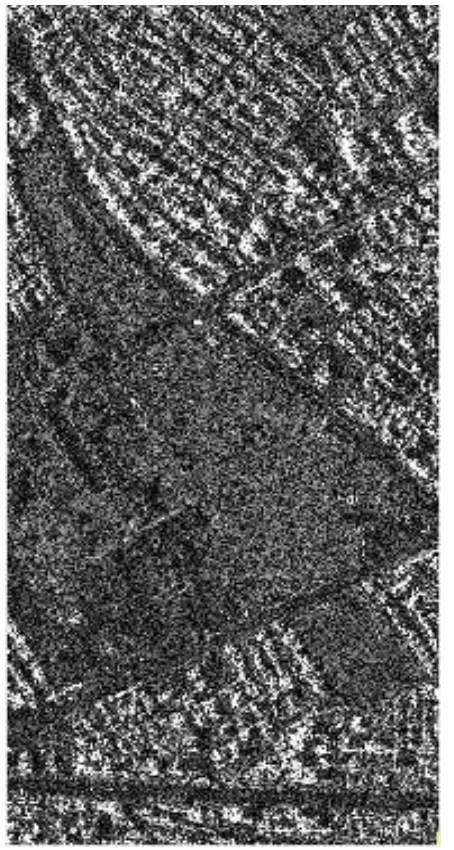

(الف)

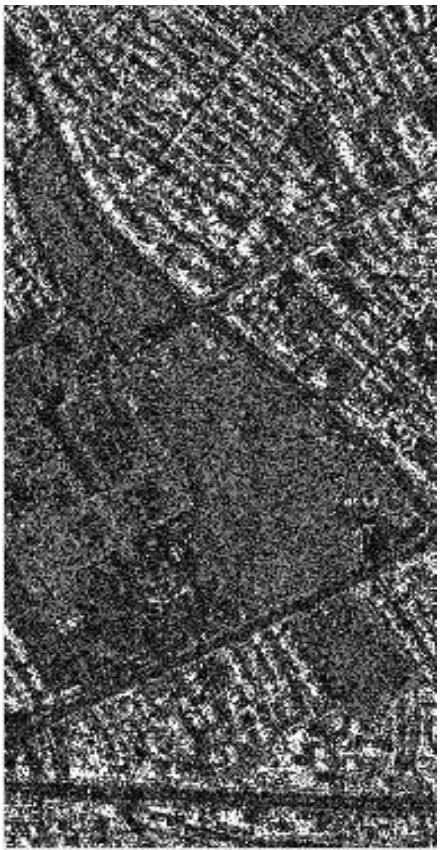

(ب)

(ت)

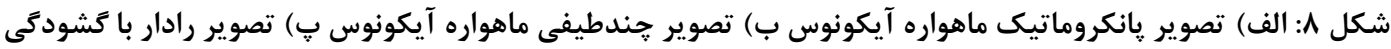

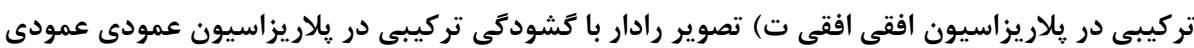

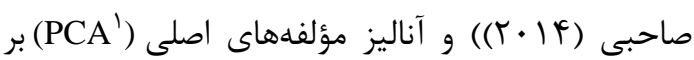
بخشى از منطقهى بالا (شكل (9)) يرداخته شده است.

${ }^{1}$ Principal Component Analysis
در اين مرحله به مقايسهى، سه روش مختلف تلفيق تصاوير شامل تلفيق در سطح ويزگى (روش ييشنهادى ما)، آى اج اس (روش ريشنهادشده توسط قنبرى و 


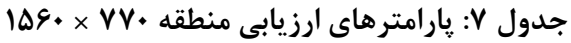

\begin{tabular}{|c|c|c|c|c|c|c|}
\hline \multicolumn{3}{|c|}{ تلفيق در سطح ويز } & \multicolumn{3}{|c|}{ استفاده مجزا از داده } & استر اتثى \\
\hline يانكروماتيك+رادار+جندطيفى & رادار+جندطيفى & يانكروماتيك++رادار & جندطيفى & 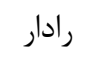 & يانكروماتيك & داده ورودى \\
\hline rr & سז & TF & זr & 11 & ra & نرون \\
\hline$q \cdot . r \cdot$ & 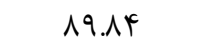 & 10.19 & 19.19 & VA.Dr & $\vee \Delta . \varphi$. & دقت كلى \\
\hline$\Lambda \cdot . f^{c}$ & $\vee 9.8 \wedge$ & V.r. & VT.TT & $\Delta V \cdot \cdot F$ & $\Delta 1 . T$. & ضريب كايا \\
\hline $91.1 \mathrm{r}$ & $q \cdot . r F$ & 14.19 & $\Lambda F . \Delta G$ & $\Lambda T . \Lambda$ & $\varepsilon \wedge . Y^{f}$. & شاختاسايى \\
\hline
\end{tabular}
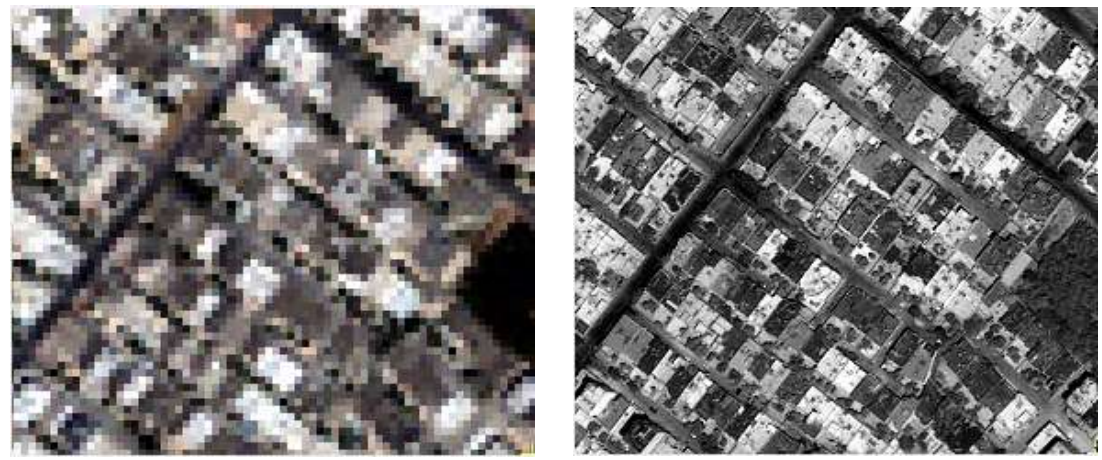

$\varphi$

الف

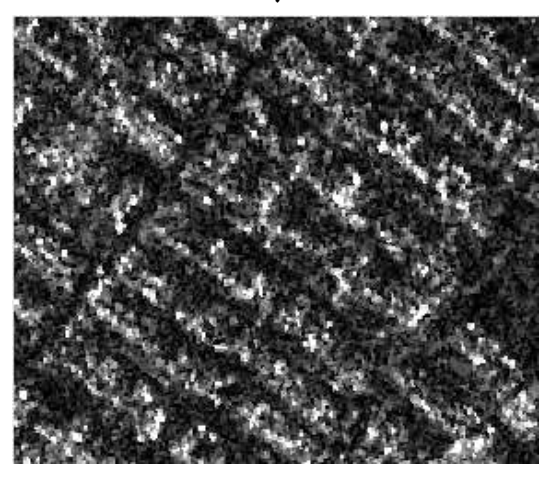

$ت$

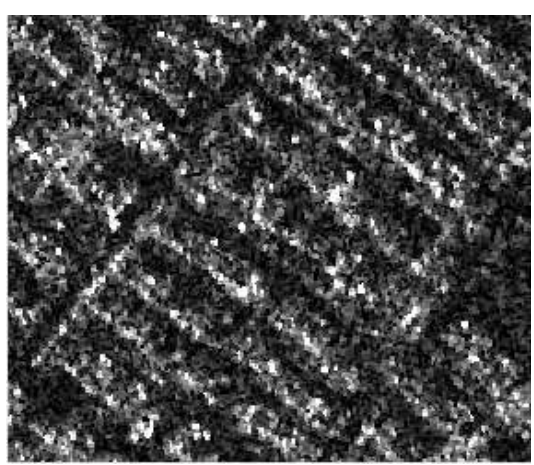

证

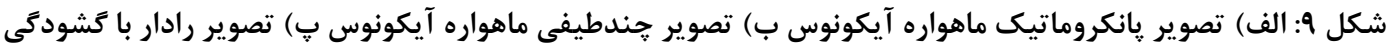

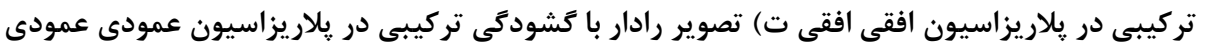

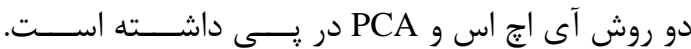

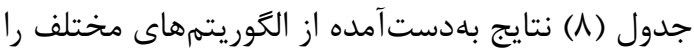
نشان مى دهد.
نتايج نشان مسى دهـد كـهـ روش زيشـــهادى مـا، جهـت تلفيق تصاوير نتايج بهترى را جــه در مرحلـه تلفيـق در سطح ويزگى تصاوير رادار+جندطيفى و همجنين تلفيق

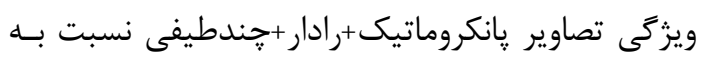


شناسايى ساختمان در مناطق شهرى با استفاده از تلفيق....

مريم تيمورى، مهدى مختارز اده و محمدجواد ولدان زوج

جدول ^: مقايسهى يارامترهاى ارزيابى روش يِيشنهادى با روش قنبرى و صاحبى در مقاله [بץ[ و آناليز مؤلفههاى اصلى

\begin{tabular}{|c|c|c|c|c|}
\hline دقت شناسايى ساختمان & 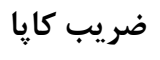 & 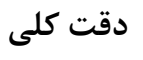 & \multicolumn{2}{|c|}{ الكوريته پِيادهسازى شده } \\
\hline 91.9 . & $\Lambda T . Y \Delta$ & $94 \cdot r$ & رادار+جندطيفى & \multirow{2}{*}{ تلفيق در سطح ويثزى } \\
\hline$q \cdot . \wedge \Delta$ & NF.rq & $9 r . \wedge \cdot$ & يانكروماتيك+رادار +جندطيفى & \\
\hline$\wedge \Delta . \cdots$ & VY.G. & $\wedge \vee .1 \vee$ & \multicolumn{2}{|c|}{ آى اج اس (روش پيشنهادشده توسط قنبرى و صاحبى (Y (Y)) } \\
\hline$\wedge ґ . .$. & ט.r. & 1... & \multicolumn{2}{|c|}{ آناليز مؤلفههاى اصلى(PCA) } \\
\hline
\end{tabular}

ساختمان از يوشش هاى گياهى نبوده است درحسالى كـه

تصاوير نورى توانايى بيشترى در تمايز بين اين دو دارد. با بررسى هاى صورت گرفته در اين تحقيق مشخص شد

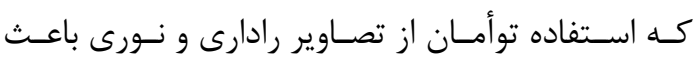
افزايش دقت در شناسـايى سـاختمانهـا شـده اسـت و و تلفيق در سـطح ويزگگى بــا اسـتفاده از شـــكه عصـبى بر روى بـردار ورودى متشــكل از ويزگَىىهـاى تصـاوير ״انكروماتيك، جندطيفى و رادارى، روش بهينهاى بـراى شناسايى ساختمان مى باشد. نتايج حاصل نشان داد كـه روش بهينه تلفيق شناسايى ساختمانهـا، حـداقل . ضــريب كايــا، F/ دقـت كلــى و V\% دقـت شناسـايى ساختمانها را نسـبت بــه اسـتفاده مجـز از منــابع داده افزايش داده است. همجِنين استراتثى تلفيق پييشنهادى منجر بـ حداقل ^ برابر همخَنى نتايج شناسايىشـده در انواع مختلف يشتبامها شده است. در مطالعـات آينـده،

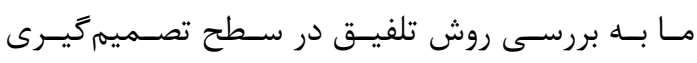
تصاوير رادار و ايتيك مىيردازيهم.

[1] Y. Zhang, "Optimisation of building detection in satellite images by combining multispectral classification and texture filtering," ISPRS Journal of Photogrammetry and Remote Sensing, vol. 54, pp. 50-60, 1999.

[2] J. A. Benediktsson, M. Pesaresi, and K. Amason, "Classification and feature extraction for remote sensing images from urban areas based on morphological

\section{F}

در اين مقالـه، بـهـ بررسـى حالـتهــاى مختلـف تلفيـق

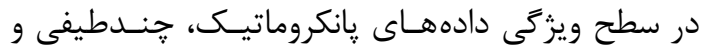

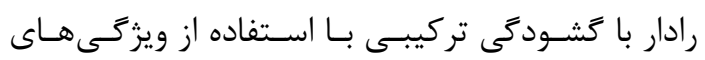

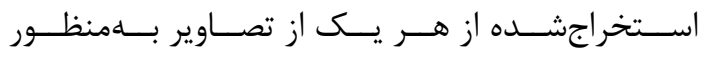
تشخيص ساختمان با حـد تفكيـك بـالا يرداختـه شـد. نتـايج حاصــل از مقايســه كيفـى و كمسى الخـوريتمهـــا

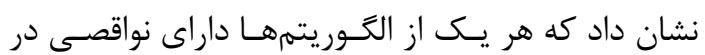
شناسايى ساختمان مىباشد. درحالى كه هر يك از آنها

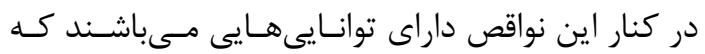

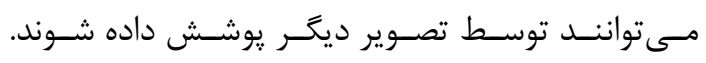
همانطور كه در تحقيق نشان دادهشده است در تصاوير نورى در برخى مناطق ييكسلهاى راه بهاشتباه بهعنوان ييكسل ساختمان شناسايى شده اسـت و ايسن بـهـ دليـل

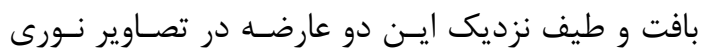
مىباشد درحالى كـهـ تصـاوير رادار داراى بافت متفــاوت مىباشد. تصاوير رادار در برخى مناطق قادر بـه تفكيـى

\section{مراجع}

transformations," Geoscience and Remote Sensing, IEEE Transactions on, vol. 41, pp. 1940-1949, 2003.

[3] A. K. Shackelford and C. H. Davis" ,A combined fuzzy pixel-based and objectbased approach for classification of highresolution multispectral data over urban areas," Geoscience and Remote Sensing, IEEE Transactions on, vol. 41, pp. 2354- 
2363, 2003.

[4] X. Jin and C. H. Davis, "Automated building extraction from high-resolution satellite imagery in urban areas using structural, contextual, and spectral information," EURASIP Journal on Applied Signal Processing, vol. 2005, pp. 2196-2206, 2005.

[5] S. Mayunga, D. Coleman, and Y. Zhang, "A semi-automated approach for extracting buildings from QuickBird imagery applied to informal settlement mapping," International Journal of Remote Sensing, vol. 28, pp. 2343-2357, 2007.

[6] A. Turlapaty, B. Gokaraju, Q. Du, N. H. Younan, and J. V. Aanstoos" ,A hybrid approach for building extraction from spaceborne multi-angular optical imagery," Selected Topics in Applied Earth Observations and Remote Sensing, IEEE Journal of, vol. 5, pp. 89-100, 2012.

[7] J. Zhao, Q. Zhu, Z. Du, T. Feng, and Y. Zhang, "Mathematical morphology-based generalization of complex 3D building models incorporating semantic relationships," ISPRS Journal of Photogrammetry and Remote Sensing, vol. 68, pp. 95-111, 2012.

[8] J. Wang, X. Yang, X. Qin, X. Ye, and Q. Qin, "An Efficient Approach for Automatic Rectangular Building Extraction From Very High Resolution Optical Satellite Imagery," 2015.

[9] M. Turker and D. Koc-San, "Building extraction from high-resolution optical spaceborne images using the integration of support vector machine (SVM) classification, Hough transformation and perceptual grouping," International Journal of Applied Earth Observation and Geoinformation, vol. 34, pp. 58-69, 2015.

[10]E. Simonetto, H. Oriot, and R. Garello, "Rectangular building extraction from stereoscopic airborne radar images,"
Geoscience and Remote Sensing, IEEE Transactions on, vol. 43, pp. 2386-2395, 2005.

[11]F. Tupin, H. Maitre, J.-F. Mangin, J.-M. Nicolas, and E. Pechersky, "Detection of linear features in SAR images: application to road network extraction," Geoscience and Remote Sensing, IEEE Transactions on, vol. 36, pp. 434-453, 1998.

[12] R. Chellappa, "Advanced Automatic Target Recognition," DTIC Document1998.

[13]F. Dell'Acqua and P. Gamba, "Texturebased characterization of urban environments on satellite SAR images," Geoscience and Remote Sensing, IEEE Transactions on, vol. 41, pp. 153-159, 2003.

[14] M. Stasolla and P. Gamba, "Spatial indexes for the extraction of formal and informal human settlements from high-resolution SAR images," Selected Topics in Applied Earth Observations and Remote Sensing, IEEE Journal of, vol. 1, pp. 98-106, 2008.

[15] Y. Wang, F. Tupin, C. Han, and J.-M. Nicolas, "Building detection from high resolution POLSAR data by combining region and edge information," in Geoscience and Remote Sensing Symposium, 2008. IGARSS 2008. IEEE International, 2008, pp. IV-153-IV-156.

[16] Y. Dong, H. Chen, D. Yu, Y. Pan, and J. Zhang, "Building extraction from high resolution SAR imagery in urban areas," Geo-spatial Information Science, vol. 14, pp. 164-168, 2011.

[17]Y. Cao, C. Su, and J. Liang, "High resolution SAR building detection with scene context priming," in Signal Processing (ICSP), 2012 IEEE 11th International Conference on, 2012, pp. 1791-1794.

[18]L. Zhao ,X. Zhou, and G. Kuang, "Building detection from urban SAR image using building characteristics and contextual 
شناسايى ساختمان در مناطق شهرى با استفاده از تلفيق... مريمم تيمورى، مهدى مختارز اده و محمدجواد ولدان زوج

information," EURASIP Journal on Advances in Signal Processing, vol. 2013, pp. 1-16, 2013.

[19]F. Tupin and M. Roux, "Detection of building outlines based on the fusion of SAR and optical features," ISPRS Journal of Photogrammetry and Remote Sensing, vol. 58, pp. 71-82, 2003.

[20]H. Sportouche, F. Tupin, and L. Denise, "Extraction and three-dimensional reconstruction of isolated buildings in urban scenes from high-resolution optical and SAR spaceborne images," Geoscience and Remote Sensing, IEEE Transactions on, vol. 49, pp. 3932-3946, 2011.

[21] V. Poulain, J. Inglada, M. Spigai, J.-Y. Tourneret, and P. Marthon, "High-resolution optical and SAR image fusion for building database updating," Geoscience and Remote Sensing, IEEE Transactions on, vol. 49, pp. 2900-2910, 2011.

[22]Z. Ghanbari and M. R. Sahebi, "Improved IHS Algorithm for Fusing High Resolution Satellite Images of Urban Areas," Journal of the Indian Society of Remote Sensing, vol. 42, pp. 689-699, 2014.

[23]J. Richards Remote Sensing Digital Image Analysis: Introduction, Second ed. New York: Springer, 1993.

[24] R. M. Haralick, K. Shanmugam, and I. H. Dinstein, "Textural features for image classification," Systems, Man and Cybernetics, IEEE Transactions on, pp. 610621, 1973.

[25] M. Haghighat, S. Zonouz, and M. AbdelMottaleb, "Identification Using Encrypted Biometrics," Computer Analysis of Images and Patterns, pp. 440-448, 2013.

[26]H. Anys, A. Bannari, D. He, and D. Morin, "Texture analysis for the mapping of urban areas using airborne MEIS-II images," in Proc. First International Airborne Remote Sensing Conference and Exhibition,
Strasbourg, France, 1994, pp. 231-245.

[27]D .Brunner, L. Bruzzone, A. Ferro, and G. Lemoine, "Analysis of the reliability of the double bounce scattering mechanism for detecting buildings in VHR SAR images," in Radar Conference, 2009 IEEE, 2009, pp. 16.

[28] R. Guida, G. Franceschetti, A. Iodice ,D. Riccio, G. Ruello, and U. Stilla, "Building feature extraction via a deterministic approach: Application to real high resolution SAR images," in IEEE International Geoscience and Remote Sensing Symposium, 2008, pp. 2681-2684.

[29]F. A. Al-Wassai, N .Kalyankar, and A. A. Al-Zaky, "Multisensor Images Fusion Based on Feature-Level," arXiv preprint arXiv:1108.4098, 2011. 


\title{
Building Detection in Urban Areas using Features Fusion of Optical and Radar Images in Neural Networks
}

\author{
Maryam. Teimouri*1 ${ }^{1}$, Mehdi Mokhtarzade ${ }^{2}$, Mohamad Javad Valadan Zouj ${ }^{3}$ \\ 1- MSc in Remote Sensing, K. N. Toosi University of Technology, Tehran, Iran \\ 2- Associate Professor in Photogrammetry and Remote Sensing, K. N. Toosi University of Technology, Tehran, Iran \\ 3- Professor in Photogrammetry and Remote Sensing, K. N. Toosi University of Technology, Tehran, Iran
}

\begin{abstract}
In this paper high-resolution SAR, panchromatic and multispectral images are fused for building detection purposes. This fusion is aimed to compensate the defects and shortcomings of these individual data sets. For this reason at first these three data sets are considered individually where some proposed input features are used for building detection. Then these features are fused in different combinations and the results are compared. In all experiments neural networks are applied and their performances are evaluated over different cover types of building roofs. It was discovered that the optimum fusion solution improves the building detection for more then $10 \%$ kappa coefficient. Also the proposed fusion strategy caused at least 8 times betters homogeneity of detection results over different roof types. The proposed method enjoying overall accuracy, kappa coefficient and building detection accuracy of\% 87.11, \% 67.99 and\%89.08 respectively confirms the ability to detect buildings of multi-resource radar and optical data.
\end{abstract}

Key words: building detection, fusion, radar image, optical image, neural networks 